\title{
Pontoppidans Danske Atlas og Slesvig
}

\author{
Af LARS N. HenNingsen
}

Slesvig-bindet af Erik Pontoppidans berømte topografiske værk "Den Danske Atlas" udkom $i$ 1781. Det er et vigtigt kildeskrift om Sonderjyllands topografi og historie med to ansigter. Sogn for sogn rummer det santikuariske" oplysninger om oldtidsminder, kirker, herregårde og lokale rariteter, og desuden giver det mange steder en bred beskrivelse af befolkningens levevilkair, næringsliv og økonomisk-sociale og kulturelle forhold, som de tog sig ud i 1760'erne og 1770'erne. De antikvariske oplysninger er udtryk for en zldre tradition og bygger mest pa forarbejder af Laurids de Thurah $i 1750$ 'erne. Den samtidsbeskrivende del representerer en yngre tradition med rod $i$ oplysningstiden. Værket forener således to forskellige traditioner $i$ den topografiske litteratur. Det kombinerer to tidsaldre.

Pontoppidans Atlas ${ }^{1}$ er et begreb - men man skal ikke læse længe i det berømte værk, før man lægger mærke til, at det skæmmes af støberande. I afsnittene om sognene i Haderslev amt f.eks. fylder bagudrettede, historiske oplysninger om kirker og herregårde hovedparten af pladsen, og der er ikke mange oplysninger dateret senere end 1750'erne. Anderledes er det f.eks. i Tønder amt. Her har flere sognebeskrivelser karakter af en bred skildring af næringslivets tilstand helt frem til 1768, flere steder er oplysningerne fort ajour op til sidst $i$ 1770'erne. Nogle bybeskrivelser går endnu længere frem, Flensborgs således til 1780. Det rejser flere spørgsmål: Hvorfor er der så stor forskel fra afsnit til afsnit, og hvorfor bærer værket Pontoppidans navn? - Erik Pontoppidan døde jo i 1764, og værket udkom først i 1781.

\section{Topografisk historie}

For at finde et svar må vi begynde søgningen tilbage i 1730'erne. Den unge Jacob Langebek var dengang godt i gang med at grundlægge sit senere ry som en af 1700-årenes fremtrædende historiske kildesamlere. Hans karriere kulminerede med stillingen som gehejmearkivar fra 1748 til hans død i 1775. I 1730'erne var han ansat til at udgive 
tidsskriftet Dänische Bibliothec, som bragte afhandlinger, kilder og anmeldelser til dansk og nordisk historie - især henvendt til et udenlandsk publikum. Da første bind var færdig til udgivelse i 1737, sendte Langebek den tidligere embedsmand og gehejmearkivar Frederik Rostgaard følgende vers ${ }^{2}$

Thi Øiemerket er: At frelse mange Ting, Som skiødesløse Folk, og Tidens Vexling øder,

At faae det danske Navn i Rygte rundt omkring,

Saavel hos Fremmede, som dem vor Danmark føder.

Versene siger noget centralt om tiden, om det historisk-antikvariske arbejde og om motivationen bag det.

Netop i 1730'erne nød historisk-antikvarisk arbejde stor bevågenhed på højeste sted hos Christian 6. i København. I 1737 udkom loven om danefæ, og kongen støttede oprettelsen af to lærde selskaber, som begge tog sig af historiestudiet, nemlig Videnskabernes Selskab i 1743 og Det kongelige danske Selskab for Fædrelandets Historie i 1745. Kongen så gerne, at der blev udgivet værker, som fastholdt og udbredte kendskabet til Danmark-Norges glorværdige historie, monarkiernes topografi og antikviteter. Sådanne bøger skulle udkomme på dansk for danskerne og på tysk og fransk for udlændinge. De skulle gøre det danske monarki kendt ude i Europa som ældgammel kulturnation. Det gjaldt om at "brande“ Danmarks glorværdige historie $\mathrm{i}$ ind- og udland. Slesvig hørte til fædrelandet på lige fod med Kongeriget. Netop i Christian 6.s dage og i midten af århundredet var der stor opmærksomhed omkring båndene mellem Kongeriget og Slesvig og af betydningen af det danske sprog i Slesvig. ${ }^{3}$ Hertugdømmet indgik i det historiske arbejde på lige fod med Danmark. Interessen samlede sig mest om den gamle historie, om antikvarisk-topografiske emner og ikke om samtidens historie. Sådan var der arbejdet siden Ole Worm forst i 1600-årene indsamlede oplysninger om runesten og andre oldtidsmonumenter. I $1730^{\prime}$ erne fik traditionen ny næring, da unge folk som præsten Erik Pontoppidan, historikeren Jacob Langebek, arkitekten Laurids de Thurah og Pontoppidans svoger Hans de Hofman tog fat, hvor de gamle slap. Laurids de Thurah blev en særlig typisk repræsentant for den gamle tradition. 


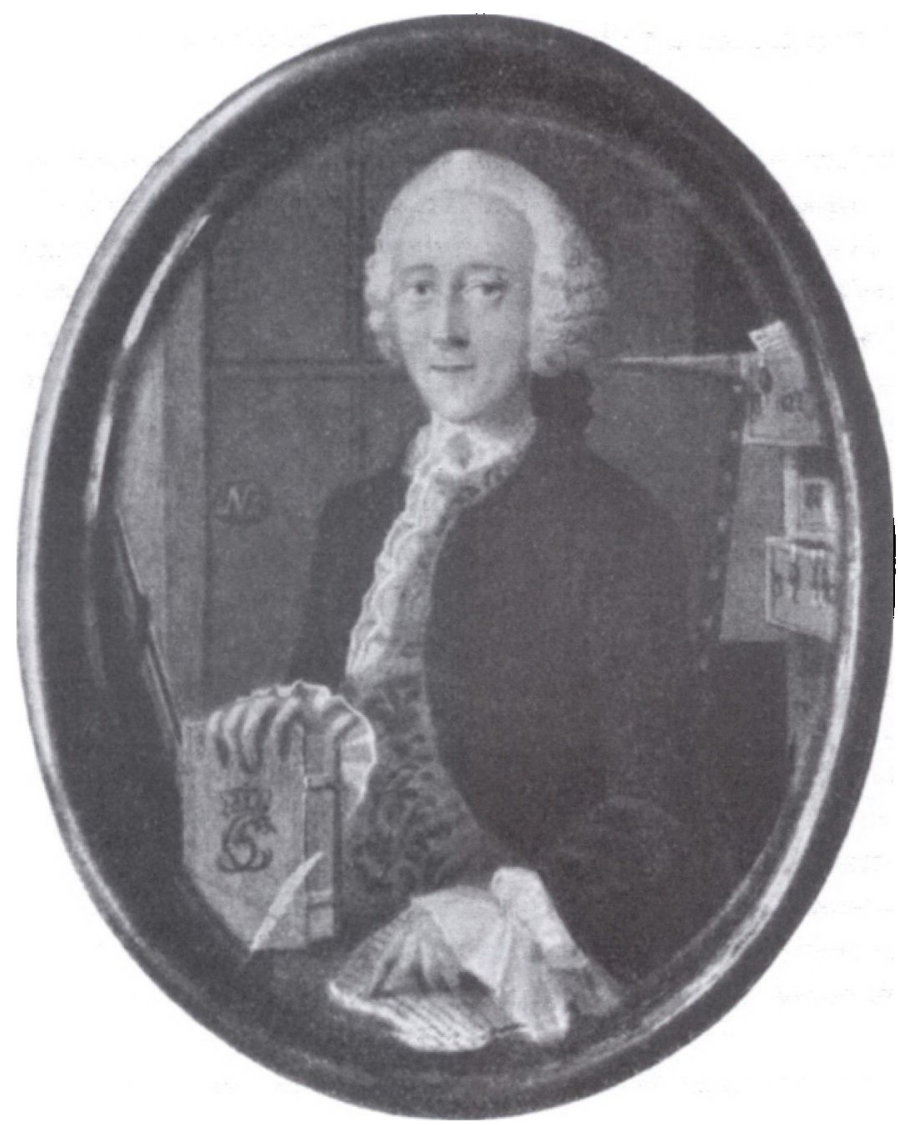

"Til hans ufuldfarte Verker hører ... Den 7deTome af danske Atlas, indeholdende Beskrivelsen over Hertugdommet Slesvig, som udkom i Trykken 1781.« Sådan skrev historikeren P.F. Suhm i sin nekrolog over Jacob Langebek (1710-1775). Pa titelbladet til »Den Danske Atlas" figurerede Langebek dog ikke, dér stod kun Pontoppidans nawn, fra bind 4 suppleret af swogeren Hans de Hofman. Men Langebeks bidrag til Slesvig-bindet havde varet betydeligt. Hans antikvariske interesser blev afgorende for afsnittet om Slesvig by, og hele Slestig-bindet stod $i$ gald til hans imponerende seddelkartotek med oplysninger fra et livslangt arkivarbejde. Det var også Langebek, som $i 1768$ udsendte en rundskrivelse til lokale embedsmænd og praster $i$ Slesvig, som skaffede store dele af stoffet til værket. Arkivtegneren Søren Abildgaards miniatureportræt fra 1751 viser geheimearkivar Langebek med hainden pä Christian 5.5 lowbog og med arkivskabe og skuffer fyldte med seglbehængte pergamentdiplomer bag sin stol. Gengivet efter Bjørn Kornerup: Det Kongelige Danske Selskab for Fædrelandets Historie 1745-1945, 1945. 


\section{Laurids de Thurah og indberetningerne til Atlas Daniæ 1754}

Thurah var Frederik 4.s og især Christian 6.s "opfindelse«. Han var bispesøn fra Ribe og gjorde efter en studierejse i udlandet fra 1732 lynkarriere som Christian 6.s bygmester. Han opførte de kongelige slotte Hirschholm/Hørsholm og Eremitagen og tegnede Sorø Akademi. I 1735 gav kongen ham i opdrag at udarbejde et stort værk om fædrelandets bygningskunst. Første bind af det fornemme to-binds værk udkom i 1746 under titlen Den danske Vitruvius. Det rummede beskrivelser og kobberstik af fremtræedende offentlige og private bygningsværker. ${ }^{4}$ Hertugdømmerne var med i værkets andet bind, som udkom i 1749. Under forarbejdet indhentede Thurah oplysninger hos den kendte rektor O.H. Moller i Flensborg og hos præster og andre kyndige folk syd for Kongeåen. Også embedsmænd rundt om i Slesvig blev taget med på råd, og han forhørte sig, hvordan salget kunne fremmes bedst muligt. ${ }^{5}$

I 1752 fattede Thurah en ny plan. Han ville gennemfore det, som aldrig var lykkedes for 1600-årenes store topografiske forfatter Peder Hansen Resen. Thurah tænkte sig et topografisk-antikvarisk storværk Atlas Daniæ. Det skulle være en fortsættelse af Den danske Vitruvius, på i alt 8 bind. Slesvig skulle have det næstsidste bind, og Holsten, Oldenburg og Delmenhorst det sidste. ${ }^{6}$ Kongen gav sin støtte til planen.

Thurah begyndte arbejdet i 1754. Han havde brug for oplysninger fra stedkendte folk ud over hele landet og gennemførte en større spørgeskema-aktion. I Kongeriget sendte han spørgeskemaerne til bisperne, som blev bedt om at lade dem gå videre til de stedkendte sognepræster. De skulle besvare 6 eller 7 antikvariske og topografiske spørgsmål. ${ }^{7}$ Syd for Kongeåen valgte Thurah at gå via amtmændene. Den 4. marts 1754 sendte han dem et tysksproget brev med bilag. »Hans kongelige Majestæt Vor allernådigste konge og herre, " skrev han i brevet, "har nådigst behaget at pålægge mig at anvende al tænkelig møje og flid på gennem offentligt tryk at fremlægge for publikum en pålidelig og nøjagtig beskrivelse af alle provinser i kongeriget Danmark og Norge samt fyrstedømmer og grevskaber.« Projektet havde været $\mathrm{i}$ arbejde $\mathrm{i}$ flere år, nu skulle det fortsætte med Jylland, »hvortil hertugdømmet Slesvig under det bekendte navn Sønderjylland er en del«. Thurah gav sin skrivelse vægt ved at fremhæve, at 
han optrådte »i kongens tjeneste og til befordring af fædrelandets gloire«.

Målet var en sandfærdig og solid beskrivelse, som kunne give fædrelandet berømmelse og højagtelse i udlandet. Med brevet fulgte en »designation « på 6 punkter, som angav de spørgsmål, Thurah ønskede besvaret. Thurah bad den enkelte amtmand indkalde besvarelse fra alle sine undergivne verdslige og gejstlige embedsmænd. Når svarene var indløbet, skulle de sendes samlet som tjenestepost til Thurah i Ålborg. ${ }^{8}$

Amtmændene sendte spørgsmålene videre til sognepræsterne via provsterne. Kun for landskaberne Stapelholm og Ejdersted gik vejen direkte fra amtet til præsterne. ${ }^{9}$

Spørgsmålene i den omtalte 6 punkt-designation ${ }^{10}$ viser, at Thurah især var ude efter oplysninger i den "gammeldags«antikvarisk-historiske tradition. Der skulle oplyses om:

1. Mærkværdige antikviteter, monumenter, begravelser og epitafier $\mathbf{i}$ by-, sogne- og annekskirker, om inskriptioner på epitafier, døbefonte, altergenstande, klokker og deslige, om årstal og adelige våben på kirken selv eller på kirkeornamenter, om gamle historier vedr. kirkerne og deres navn før reformationen, om kirkebygningen var "sirlig" og med eller uden tårn.

2. Hvilke og hvor mange landsbyer der var i hoved- og annekssognet og deres navne.

3. Oprindelsen til landsbyernes navne.

4. Hospitaler, skoler og lignende offentlige stiftelser, af hvem og hvornår de var stiftet og deres indretning.

5. Adelige gårde, deres navne, nuværende ejere, historie, årstal og inskriptioner. Om de før havde andre navne. Om de er grundmurede, med tårn og har sådanne ornamenter, at de fortjener at blive stukket i kobber.

6. Hedenske monumenter, altre og grave i sognene, i landsbyerne, på markerne og i skovene, romersk-katolske helligkilder og søer og gamle historier og traditioner derom.

Det var konkrete historiske oplysninger og ikke samtidige sognebeskrivelser, Thurah ville samle i sit værk.

Præsterne gik uden tøven $\mathbf{i}$ arbejdstøjet, da de fik den kongelige Thurah-ordre. I enkelte tilfælde blev det overladt lokale civile em- 


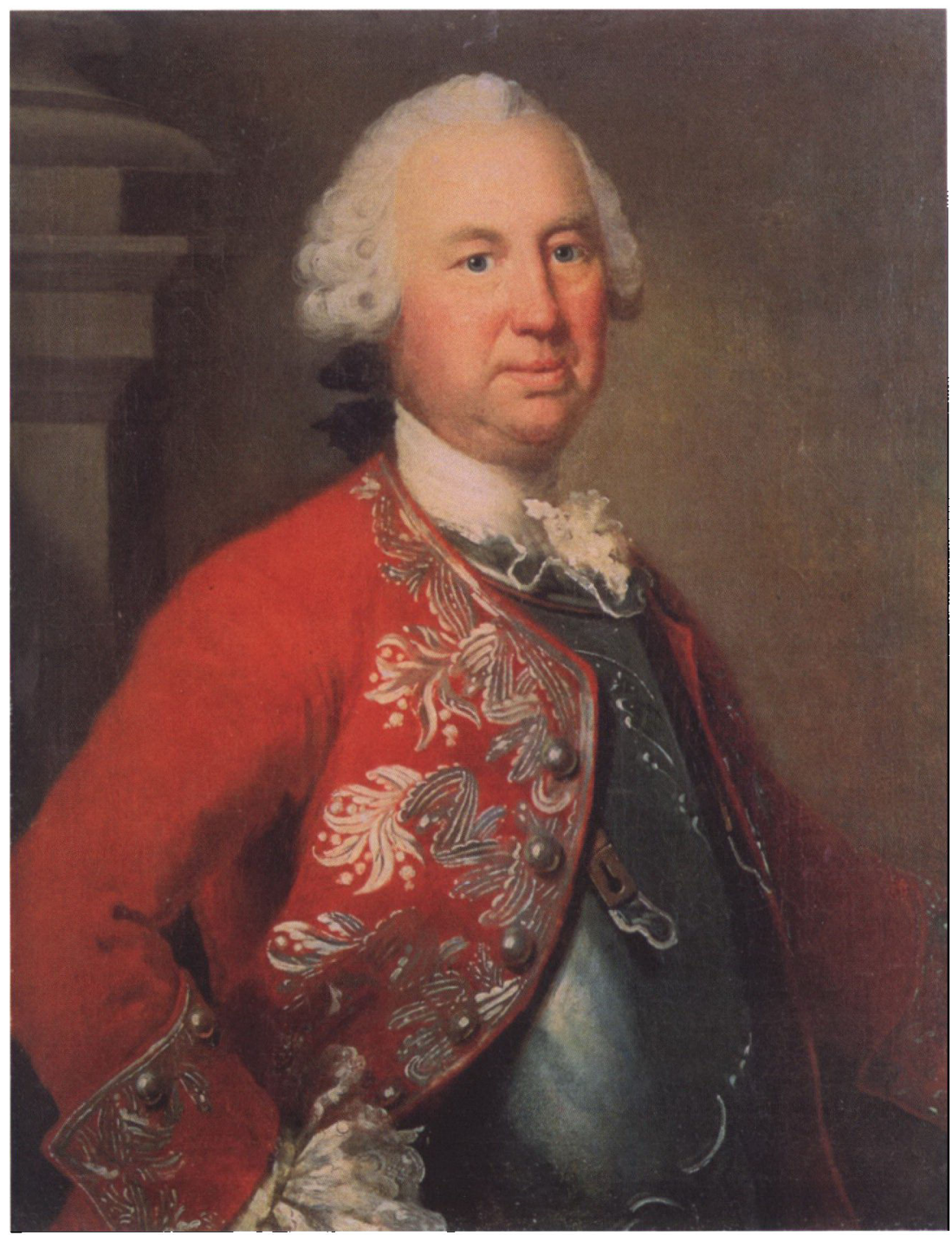

Hofbygmester, senere generalbygmester Lauritz de Thurah (1706-59) er ikke blot kendt som en af arkitekterne bag Amalienborgkzarteret $i$ Kobenhavn, men ogsa for sine fornemt udstyrede boger om Danmarks bygningsvarker. I 1750'erne begyndte han en landsdakkende indsamling af oplysninger til en historisk beskrivelse af sognene $i$ Danmark og Slesvig. De blev senere grundstammen til bl.a. Slesvig-bindet af Erik Pontoppidans storoærk "Den Danske Atlas" fra 1781. Maleri af Johan Horner (gengivet efter Gud Konge By. Frederiksstaden 250 år, Det danske Kunstindustrimuseum 1999). 
bedsmænd eller kirkeværger og sognebønder at besvare spørgsmålene. Det gjaldt f.eks. nogle af sognene i Tørninglen, hvor der var meget kongerigsk strøgods, og præsten hørte under Ribe og derfor ikke var så tilbøjelig til at svare amtmanden i Haderslev. Besvarelserne indløb allesammen hurtigt og nåede frem til amtskontorerne allerede i løbet af sommeren 1754. Kun sogne under adelige godser faldt uden for spørgerunden. Fra amterne blev de mange beretninger sendt videre til generalmajoren i Aalborg. I Flensborg tog amtskontoret afskrifter af flere beretninger, som blev henlagt $\mathrm{i}$ amtets arkiv, inden originalerne blev sendt videre. ${ }^{11}$

Da de hundredvis af præsteindberetninger nåede frem til Thurah ${ }^{12}$, gik den flittige mand straks i gang med bearbejdelsen. Men hans tid blev knap. Netop i sommeren 1754 fik Thurah for alvor hænderne fulde som arkitekt. Han blev udnævnt til generalbygmester, og det satte begrænsninger, også selvom Thurahs arbejdsevne var enorm. Han bearbejdede stoffet fra Sjælland og Fyn ${ }^{13}$, og i løbet af ganske få år fik han bøger færdige om Bornholm (1756), Amager og Saltholm (1758) samt Samsø (1758). Disse bøger blev slutstenene. Den 6. september 1759 indhentede døden den travle mand.

På dette tidspunkt var han endnu ikke kommet $i$ gang med indberetningerne fra Nørrejylland og Sønderjylland. Den kongelige plan om et Atlas Daniæ i den gamle antikvarisk-topografiske tradition lå nu ufuldendt. De store samlinger af præsteindberetninger blev afleveret hos den kongelige finansembedsmand, justitsråd Gabriel Linde, som optrådte som skiftekommissær.

\section{Slesvigske antikvarer}

Da Thurah gennemførte sin spørgeaktion i Slesvig påkaldte den sig opmærksomhed lokalt. Rundt om i hertugdømmet havde der længe været ganske mange folk, som interesserede sig for netop de emner, Thurah bragte på bane med sit spørgeskema. Præster og lærde skolefolk gravede i gamle bøger - og i jorden. I Aabenraa benyttede provst Trogillus Arnkiel i årene på begge sider af år 1700 sine visitatsrejser til arkæologiske iagttagelser. Han indhentede informationer om oldsager fra præsterne i Hammelev, Toftlund, Øster Løgum og Løjt, og de sendte ham fund fra udgravninger. Han berettede om fundene og om det berømte Gallehus guldhorn i flere bogværker mellem $1683 \mathrm{og}$ 1703. ${ }^{14}$ 


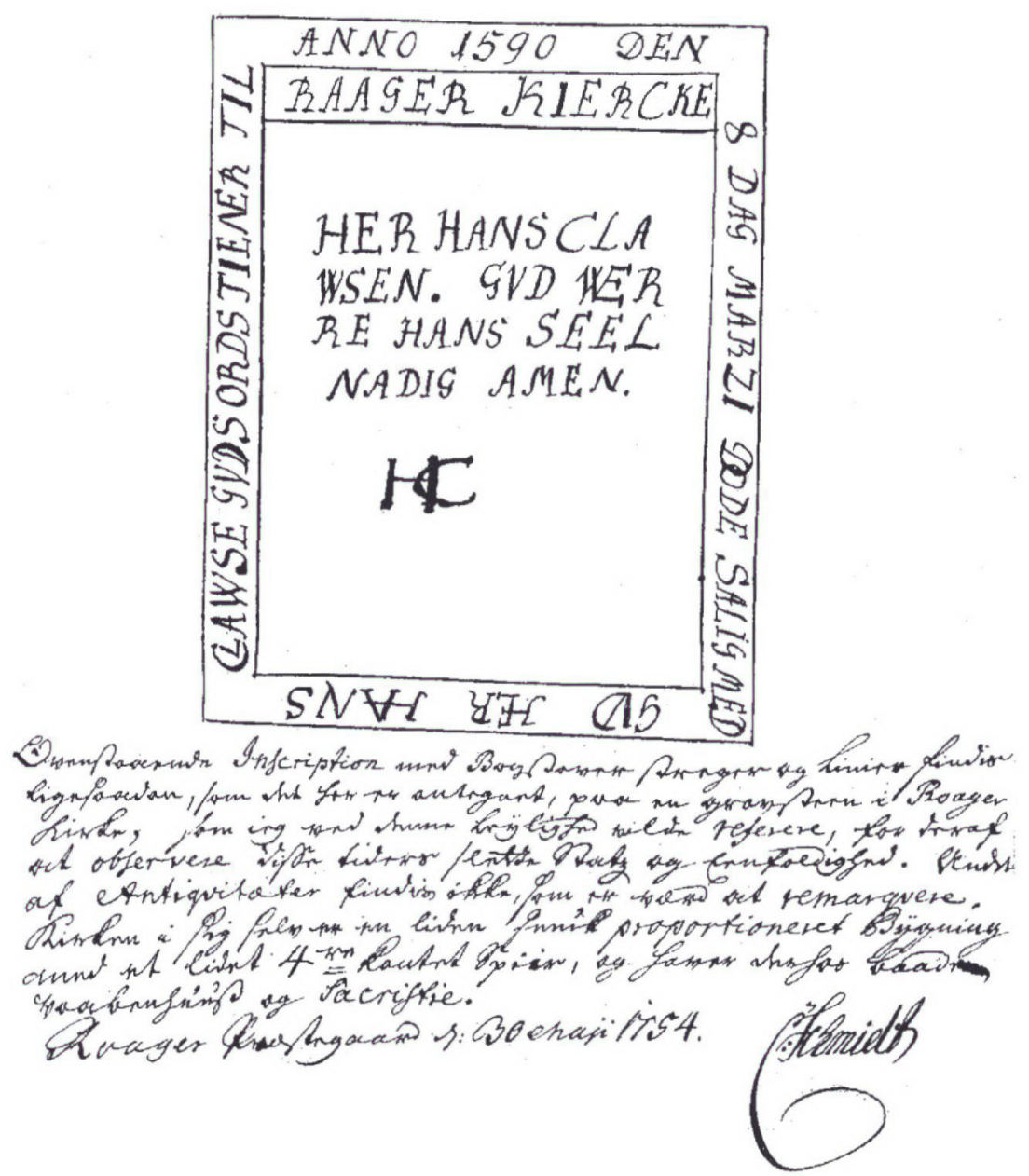

Enkelte præster supplerede indberetningen til Thurah med tegninger. Her har pastor Schmidt $i$ Roager tegnet gravstenen i kirken over pastor Hans Clawsen, d. 1590. Schmidt gjorde det "for deraf at observere disse tiders slette Statz og Eenfoldighed", som han skrev. I dag kendes gravstenen ikke mere. Tegningen er bevaret blandt Langebeks papirer. $\mathrm{Kgl}$. Bibl. Langebeks excerpter 60, 4 to.

Erik Pontoppidan, som var hofpræst i Nordborg og derefter sognepræst $\mathrm{i}$ Havnbjerg $\mathrm{i}$ årene fra 1723 til 1734, var en anden af de interesserede. Han gav sig tid til mange lokale iagttagelser $i$ sine sogne. Han undersøgte lokale "antikviteter «, folkeliv, overtro og sprog og dyrkede et bredt historisk-topografisk forfatterskab. I 1730 udkom 
hans værk Theatrum Daniæ, som var en antikvarisk topografi, en topografisk-historisk beskrivelse af Danmark og Slesvig. Han samlede også oplysninger om Slesvigs sprog og folkeminder, som blev til flere bogværker. ${ }^{15}$

Arkæologien i mere snæver forstand havde venner i flere sogne. Holbøl var kendt for »adskillige hedenske Altere og mange Gravhøje» på sine marker. I 1732 gravede sognepræsten Johannes Schneider urner frem fra højene. Pontoppidan blev underrettet, og han lod dem publicere med fine tegninger, da han senere udgav bind 1 af Danske Atlas i 1763. ${ }^{16}$ I Bylderup udgravede stedets sognepræst i årene 173366, Johannes Lou, en stor stensat oldtidshøj øst for landsbyen Lendemark og fandt tre urner med aske og en hårnål af messing. Urnerne var så skrøbelige, at de gik itu. "Så vidt man kunne se og slutte var de af ler og ikke pyntelige « skrev efterfølgeren derom $i$ en indberetning $i$ 1768. ${ }^{17}$ I Sterup i Angel havde pastor H.S. Pauli, sognepræst indtil 1757, samme interesser. Han fulgte med i tidsskriftet Dänische Bibliothec, hvor han læste Th. Broder Bircherods udgravningsberetning om fynske antikviteter, og han sammenlignede med fund i sit eget sogn, Sterup. ${ }^{18}$

En anden ivrig oldsagssamler var amtslæge Johan Christian Fabricius (1705-1775) i Tønder. Han gravede og fandt urner og genstande i Ravsted og på Sild. I Bylderup sogn fik han hjælp hos lokale bønder til at udgrave to høje tæt ved Hajstrup og fandt forskellige urner. Fabricius opbyggede et helt oldsagsmuseum af fundene. Urner og bronzefund herfra blev gengivet i første bind af Pontoppidans Danske Atlas i $1763 .{ }^{19}$ I Agerskov samarbejdede Fabricius om udgravninger med den oldsagsinteresserede sognepræst og provst Otto Riese, som selv havde skabt sig en samling af gamle mønter, naturalier og instrumenter. Læge Georg Krüsing/Krüsicke fra Flensborg (1702-51) udgravede høje på Husby mark i Angel og fandt urner med aske og knogler. Det blev til en samling af oldsager, som siden blev solgt til Berlin. ${ }^{20}$ Rundt om i byerne sad der lærde, som arbejdede med de skriftlige kilder og samlede stof til lokalhistoriske værker, således J.M. Krafft og Johann Lass i Husum og Ulrich Petersen i Slesvig. ${ }^{21}$ I Tønning publicerede rektor Johan Christoph Kleffel i 1742 en bog om marskens oldtidsminder udstyret med egne tegninger. ${ }^{22}$ I Tønder skrev pastor Martin Richard Flor om byen og om Sild, arbejder som siden blev benyttet i Den Danske Atlas.

Den mest berømte blandt de lærde slesvigere var sikkert flensbor- 


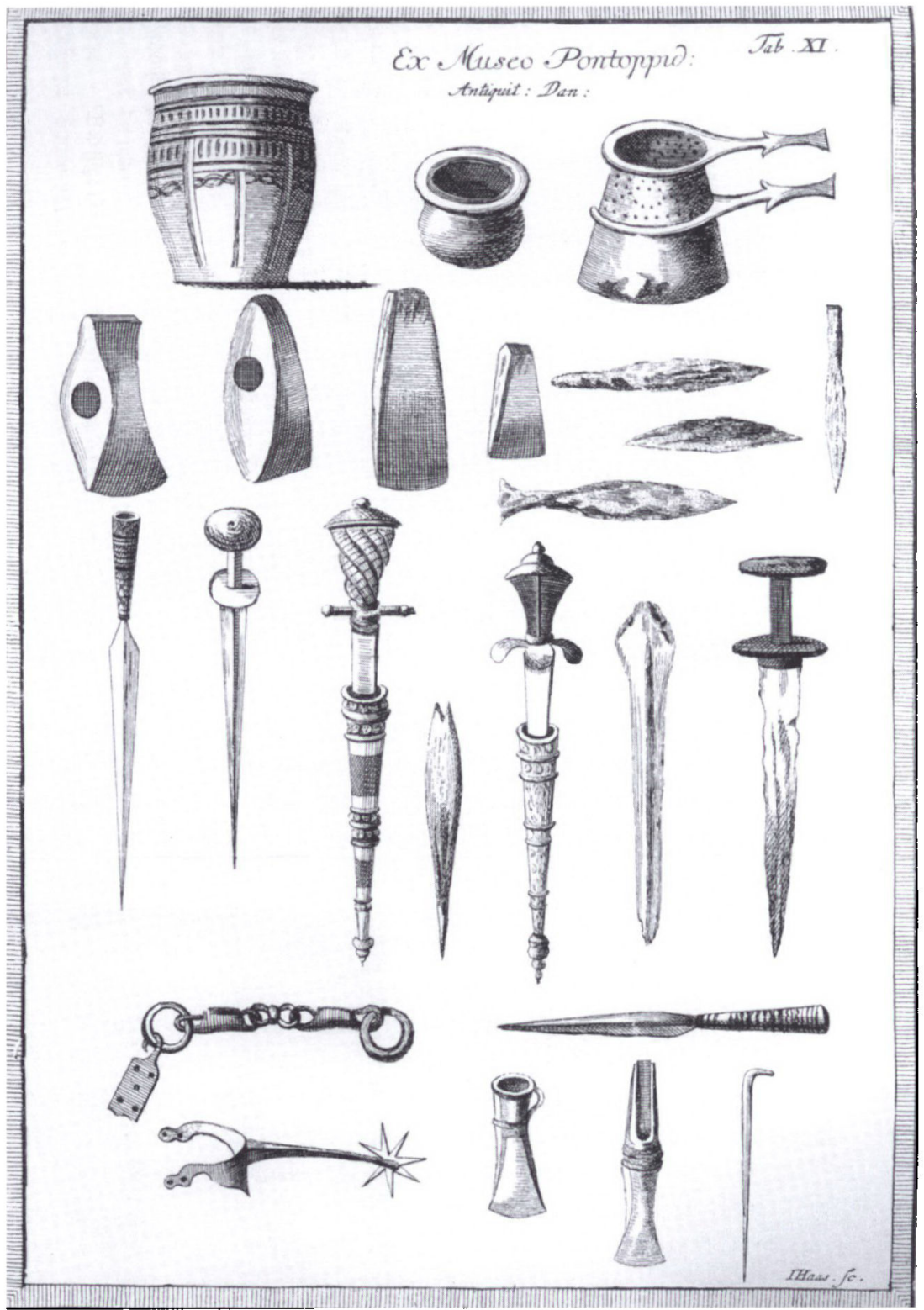

I forste bind af "Den Danske Atlas" lod Pontoppidan gengive flere samlinger af oldsager, bl.a. sit eget "museum «. Umerne skal vare udgravet $i 1732$ af pastor Johannes Schneider i Holbøl. Dengang var Pontoppidan prast på Als - sá mon ikke han har făet dem overladt af presten? 
geren O.H. Moller. Som ung akademiker gjorde han karriere i Kobenhavn, og nåede at blive professor og udgiver af det officiøse historieværk Dänische Bibliothec. Det gav kontakter til inderkredsen af danske historikere og samlere. I 1750 vendte han tilbage til sin fødeby som rektor for latinskolen. Han brændte for landsdelens historie og personalhistorie. Han fik kongelig tilladelse til at udbede sig gamle kilder til låns hos de lokale præster. ${ }^{23}$ Ofte besøgte han præstegårdene rundt om for at gøre studier i kirkebøgerne, og det hændte, at han fik historiske dokumenter med hjem. For eksempel forhørte han sig flere gange i Løgumkloster/Nørre Løgum om gamle kilder ${ }^{24}$, og han fik fat på Løgum klosters kopibog. ${ }^{25}$ I Sommersted blev der overladt ham et gammelt pergamentdokument, som var fundet $\mathrm{i}$ kirkens alter, og som gav oplysninger om kirkens indvielse. ${ }^{26}$ Moller korresponderede med en del præster ud over hele Slesvig og opbyggede et enormt bibliotek af bøger og håndskrifter, især vedr. Slesvigs historie. Op mod 13.000 bind bøger og 1.700 håndskrifter blev det til. ${ }^{27}$ Det gjorde ham kendt i samtiden, og hans bibliotek blev beundret og besøgt af folk med lignende interesser.

En af Mollers begejstrede gæster var auditør, krigsråd og ridefoged Johann Friedrich Camerer i Haderslev. I årene fra 1752 til 1792 udøvede Camerer en hektisk aktivitet som forfatter, udgiver, embedsmand og reformator. Camerer begyndte på det antikvarisk-topografiske felt. Sammen med amtslæge Fabricius på Sild foretog Camerer udgravninger. De besøgte Gallehus, hvor guldhornene var fundet, og Camerer så på gravhøje ved Schuby i Sydslesvig, ved Årøsund, Arrild og Skærbæk og langs Hærvejen. Han stod i kontakt med gravende præster, og han publicerede en række afhandlinger, hvor der blev fortalt om udgravninger, i flere tilfælde med tegninger af fundene. Lidenskabeligt gik han til forsvar for de gamle minder fra fortiden. I Skærbæk f.eks. var der mange »hedenske gravhøje«. I 1738 søgte lokale folk efter sten dér, og en dreng blev kvalt, da en høj brød sammen. Ved Hjemsted blev der oppløjet mange urner med aske og brændte ben. ${ }^{28}$ Camerer konstaterede, at der rundt om blev gravet og ødelagt mange grave. Sten blev udgravet og anvendt lokalt eller eksporteret til stenfattige egne vestover. Camerer reagerede på truslen om vidtgående ødelæggelse af de gamle minder ved i 1754 at foreslå et projekt, hvorefter han skulle berejse hertugdømmerne og Danmark for at undersøge de bevarede oldtidsminder. I 1787 og 1789 gentog han sit forsvar for oldtidsminderne. Kostbare sager gik tabt, skrev han, »fordi 
bonden efter sin opfattelse ikke ser nogen værdi i en gammel sort lerkrukke fyldt med brændte menneskeknogler og måske et kobbersværd og andre småting og næppe agter det værd at samle det op og bære det hjem. Urnen med dens knogler lader han i alt fald gå til, fordi det blot ville give djævelen lejlighed til at spoge, hvis han tog den ind $i$ sin bolig. "Som modtræk med ulovlig udførsel af oldsager burde kongens Kunstkammer indkøbe de lokale fund og sikre dem for fædrelandet. Kunstkammeret burde udvides med et særligt museum for oldsager, og Kunstkammerets forvalter skulle have pålæg om at bevare "minderne om de gamle cimbrere «. ${ }^{29}$

Senere drejede Camerer i retning af oplysningstidens reformprogram, og beskæftigede sig mere med samtidens økonomisk-sociale og erhvervsmæssige emner. Denne udvikling fra et rent historisk interessefelt til et bredere samfundsmæssigt perspektiv var typisk for perioden. Det kom også frem i forholdet mellem Thurah og Pontoppidan, som vi skal se nedenfor.

Camerers planer i 1754 minder på flere måder om Thurahs store projekt. Men den ukendte krigsråd i Haderslev havde ikke de fornemme beskyttere som Thurah, og han fandt ikke sponsorer til sit projekt.

Moller lagde selvfølgelig mærke til Thurahs aktion, og med den kongelige tilladelse til at låne dokumenter $\mathrm{i}$ hånden fik han adgang til en del af besvarelserne, inden de blev sendt til Aalborg. I Haderslev afskrev han egenhændigt og måske med hjælpere 37 beretninger fra det store amt og tog dem med til sit bibliotek i Flensborg. Her kom de på auktion, da hele samlingen blev solgt i 1796-97 efter Mollers død. I dag er de havnet i landsarkivet i Slesvig. ${ }^{30}$

\section{Pontoppidan: Den Danske Atlas}

Som nævnt døde Thurah i 1759, inden han fik de mange indberetninger bearbejdet. Det betød imidlertid ikke, at projektet blev henlagt. Netop i 1759 meldte der sig en liebhaver med usædvanlig effektivitet - det var Erik Pontoppidan. Efter at have øvet sig med historisk-topografiske arbejder i Nordborg-Havnbjerg-tiden frem til 1734 var han blevet slotspræst i Hillerød og hofpræst i København, biskop i Bergen og til sidst prokansler for Københavns Universitet. År for år publicerede han en lang række kirkehistoriske og historisk-topografiske arbejder. Med årene udvidede han også sit synsfelt. Fra midten 
af 1750 'erne blev han en del af regeringens arbejde for at fremme interessen for tidens erhvervsøkonomiske forhold og reformbestræbelser. I 1755 blev der på forslag af den almægtige overhofmarskal A.G. Moltke udsendt opfordring til befolkningen om at indsende ideer til reformer af landbrug og næringsliv. Ønsket var, at det kunne sætte gang $i$ et praktisk økonomisk reformarbejde, især inden for landbruget. Pontoppidan fik til opgave at udgive de indkomne forslag. Det skete i bogværket Danmarks og Norges oeconomiske Magazin, som udkom i syv bind mellem 1757 og 1762. Pontoppidan blev udgiver af samlingen. ${ }^{31}$ Det var med til at dreje hans interesser fra det rent historiske til den nutidige samfundsbeskrivelse. I 1760 udsendte han et stort topografisk værk om Københavns historie, Origines Hafnienses. Det blev overrakt kong Frederik 5., og ved den lejlighed lod kongen et nådigt ord falde om det onskelige $\mathrm{i}$ at værket blev videreført med en historisk egnsbeskrivelse af alle danske provinser. Det opfattede Pontoppidan som en kongelig ordre. Han svarede ved at fremlægge en plan om en stor topografisk-historisk Danmarksbeskrivelse.

Pontoppidan forestillede sig et værk $\mathrm{i}$ traditionen, som vi så den hos Thurah og hans forgængere. Men hertil satte Pontoppidan nu også en mere nutidsrettet vinkel på tingene. Han ønskede en samfunds- og egnsbeskrivelse, som i oplysningstidens ånd kunne være nyttig og give stof, som var anvendeligt for samtidens forvaltning og erhvervsliv. Derved bevægede Pontoppidan sig ud over den gamle antikvariske tradition fra 1600-årene. Han knyttede sig til oplysningstidens nytteorienterede form for statistisk-topografisk litteratur, som sidst i 1700-årene skulle blomstre i utallige sogne- og egnsbeskrivelser.

Pontoppidan var sig meget bevidst om denne værkets dobbelte karakter. I forordet til første bind i 1763 skriver han: »Følgeligen foretog jeg mig at udarbeyde vort Lands Beskrivelse, efter en gandske anden Plan, henrettet til et høyere Øyemerk, nemlig ikke alleene de historiske, men ogsaa de physiske og oeconomiske Efterretninger; thi at et saadant historisk Skrift bliver tillige pragmatisk, eller beqvemt til nogen virkelig Brug og Nytte, er uden Tvivl dets bedste Priis, mod hvilken de antiqvariske eller andre, alleene til curiositætens Fornøyelse hensigtende Efterretninger, ikke veye op, endskiønt de ogsaa i visse Ting, kunne tiene til noget Gavn, saavelsom, til Sinds Forlystelse «. ${ }^{32}$

I det følgende skal værkets dobbelthed påvises ved at se på bindet 
om Slesvig, værkets sidste og syvende bind. Af hensyn til overblikket må dog forudskikkes et par ord om hele værket og dets tilblivelse.

Pontoppidan var godt rustet til projektet. Gennem mange år havde han samlet oplysninger fra den historiske litteratur, biblioteker og arkiver. Nu fik han også tilladelse til at indhente data i administrationens arkiver, og han fik overladt en samling indberetninger om hvert "Amts naturlige, saavelsom borgerlige Tilstand og Beskaffenhed", som i 1743 var indhentet fra amtmændene i Danmark-Norge ${ }^{33}$ Særlig vigtigt var, at han fik adgang til indberetningerne til Thurah. Efter Thurahs død var de som nævnt havnet hos skiftekommissæren, justitsråd, senere etatsråd Gabriel Linde, som var embedsmand i finansadministrationen i København. ${ }^{34}$ Uopfordret overlod han materialet, eller i alt fald den kongerigske del, til Pontoppidan. Denne skriver selv, at han fik tilsendt "en god Deel hidhenhørende skriftlige Beretninger, som forefandtes efter afgangne Hr. General-Major De Thurah, og af Hans Velbr. vare indhentede, allermeest fra Biskoperne i hvert Stift, ligesom ved dem fra deres underhavende Presteskab. Der i findes vel det allermeeste af den Beskaffenhed, at det gaaer uden for min Cirkel, eller dette Skrifts egentlige Grendser. Dog findes deri ogsaa her og der, nogle hidhenhorende, heel efterrettelige og gode Anmerkninger, særdeles visse Kirker og Herregaarde angaaende. Følgeligen erkiendes ogsaa dette med offentlig Taksigelse, baade mod Samleren, som bestemmede det til sin Danske Vitruvii Fortsettelse, og mod velbemeldte Hr. Justice-Raad Linde, som ubedet og af en ædelmodig patriotisk Drift, meddelede mig det, som han holdt for, ved min Haand at kunde reddes fra Undergang og Forglemmelse ${ }_{0}{ }^{35}$

Pontoppidan havde således sikret sig et alsidigt kildemateriale, fra Thurah og fra kilder $\mathrm{i}$ administrationen. På denne basis udgav han $\mathrm{i}$ 1763 første bind af storværket Den Danske Atlas. Det indeholdt den almindelige historie, kulturhistorie og samfundsbeskrivelse. I 1764 udkom bind II om København og en del af Sjælland. Så blev også denne forfatter revet fra arbejdet. Han døde den 20. december 1764 og efterlod et næsten færdigt manuskript til bind III om resten af Sjælland, Møn, Bornholm, Fyn, Lolland, Falster og Langeland.

$\mathrm{Nu}$ måtte der igen findes en ny mand til at videreføre værket. Forlæggeren, bogtrykker Godiche, kaldte den erfarne geheimearkivar Jacob Langebek til hjælp. Langebek havde gennem mange år stået både Thurah og Pontoppidan bi med oplysninger fra sine omfattende historiske kildesamlinger. Han påtog sig straks at færdigredigere manu- 


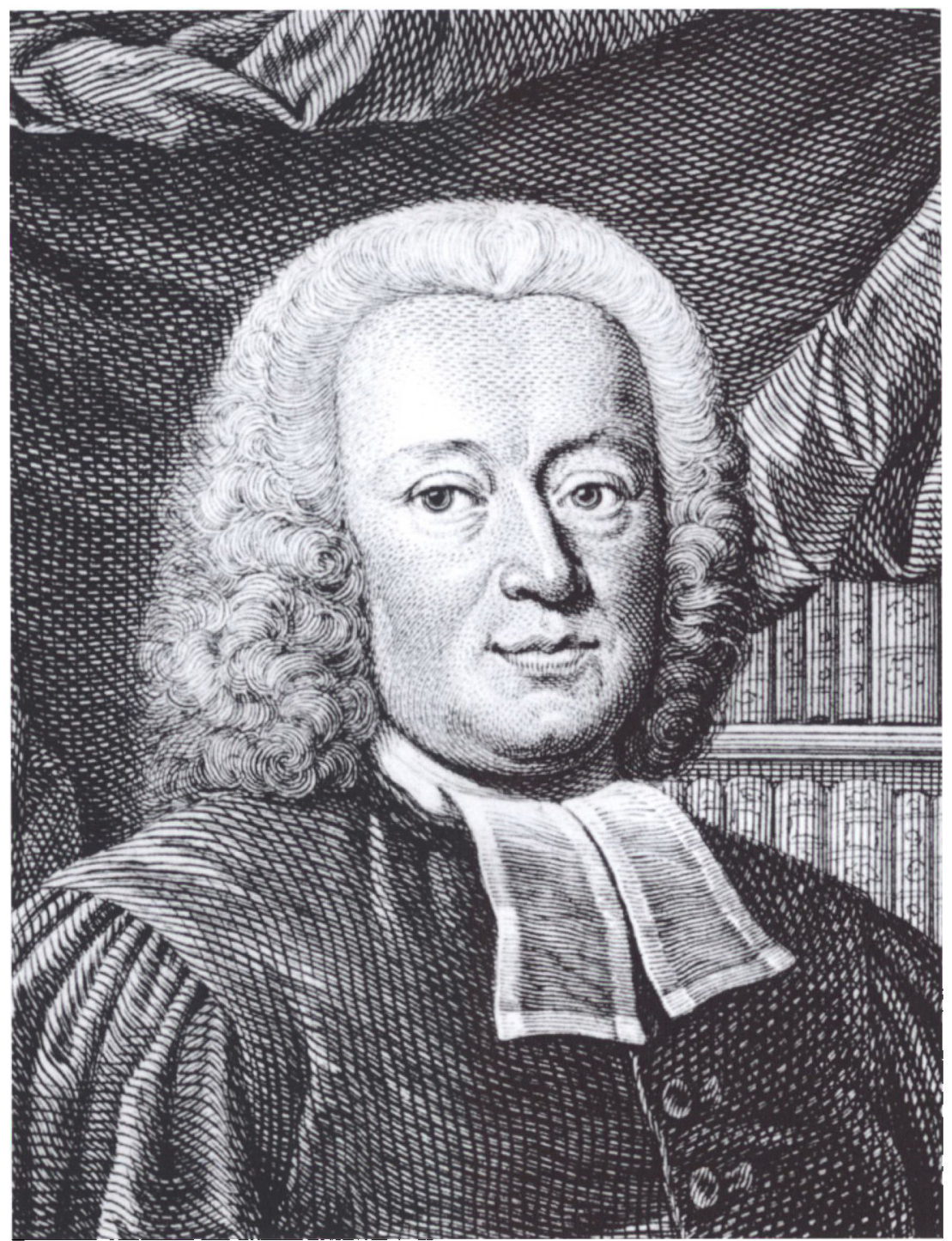

Erik Pontoppidan (1698-1764) fik en livslang karriere som gejstlig, forst som præst $i$ Nordborg, Haznbjerg, Frederiksborg-Hillerod og Kobenhavn, siden som biskop i Bergen og til sidst prokansler ved Kobenhavms universitet. Hans virksomhed som salmebogsog katekismusudgiver, polyhistor og nationalokonomisk redaktør og forfatter var imponerende. Allermest bleo hans nawn miske slået fast, da han $i 1763$ begyndte udgivelsen af storvarket Den Danske Atlas $i 7$ store bind. Kun de tre forste bind stammede dog fra hans pen. Slesvig-bindet fra 1781 havde af gode grunde helt andre fxdre end Pontoppidan. Foto: Arkivet ved Dansk Centralbibliotek for Sydslesvig. 
skriptet til bind III. Allerede i 1767 kunne det gå i trykken. Det var et lidt hurtigt arbejde, hvor det kun i begrænset omfang blev muligt at inddrage de mange historiske data fra Thurahs indberetninger.

\section{Hofman og Langebeks fortsættelse af Den Danske Atlas}

Opgaven lød herefter på at afslutte Pontoppidans værk med de manglende bind om Jylland og Slesvig. Det var et arbejde fra grunden, for der forelå ikke noget manuskript, kun de ubearbejdede indberetninger til Thurah og andre materialesamlinger. Det lykkedes forlæggeren at overtale Pontoppidans svoger Hans de Hofman til at påtage sig opgaven, i første omgang Nørrejylland. Hofman var en passioneret samler af historisk-genealogisk materiale. I årene 17551765 udgav han det store tibinds værk Hofmans Fundationer, som samlede oplysninger om landets stiftelser og indeholdt adskillige stamtavler over adelige og borgerlige familier. I sit anlæg mindede værket meget om det, Thurah havde haft i tankerne, og det benyttede i høj grad Thurah-indberetningerne, som Hofman havde fået til låns fra svogeren. Hofman var en mere grundig topograf end Pontoppidan. Derfor lagde han vægt på, at de sidste bind af Den danske Atlas skulle bringe flere lokale detaljer end værkets første, og de skulle være korrekte. Hofman korresponderede vidt og bredt med stedkendte købstadsfolk, embedsmænd og gejstlige i Jylland for at få supplerende og præcise oplysninger.

Hofman havde hænderne fulde. Fra 1760 var han præsident i Fredericia, fra 1769 desuden landkommissær og fra 1773 yderligere amtmand i Koldinghus amt. Der måtte hjælp til for at klare atlasprojektet, og den helt uundværlige hjælper blev gehejmearkivar Langebek. Han skaffede manglende informationer fra biblioteker og arkiver i København og gav manuskriptet den sidste afpudsning. Resultatet af deres fælles anstrengelser forelå med bind IV af Den danske Atlas om Aarhus og Viborg stifter i 1768 og med bind V om Aalborg og Ribe stifter i to halvbind i 1769. Bind IV og V byggede på Pontoppidans oprindelige koncept og kombinerede det historiske og det samtidsøkonomiske stof. Men takket være Hofman og Langebek blev den historisktopografiske basis i de jyske bind IV og V mere solid end i ø-bindene II og III. De helt nutidige informationer om samtidens samfund fik god plads. Tanken var, at de skulle give både befolkningen og admini- 
strationen nyttige oplysninger. Hofman fremhævede gerne, at værket var et datamateriale for administrationen, som den var nødt til at forholde sig til. I 1768, da Jylland-bindet var godt på vej, skrev han om denne dimension i et brev til Langebek: "Thi ville collegierne kaste efter og bruge den, seer de, at mange ting er gorlig på et sted, men ej paa et andet sted, amtmænd og magistrater torde ej lyve, da dette er trøkt og i hver mands eje.» ${ }^{36}$

Med denne indstilling til værket kunne de grundige herrer Hofman og Langebek ikke affinde sig med manglerne i bind II og III. Så snart Jylland var færdigbeskrevet, tog de fat på at bringe også fremstillingen af østifterne op på standard med Jylland. På grundlag af ældre indberetninger, bl.a til Thurah, og mange ny-indhentede oplysninger skabte de et supplementsbind om øerne. Det var bind VI, som forelå færdigt i 1774. Dermed var hele Kongeriget færdigt.

\section{Langebeks avertissement til Slesvig 1768}

Nu manglede kun Slesvig eller Sønderjylland, og det var måske det største problem hidtil under værkets tilblivelse. Thurah-indberetningerne fandtes stadig som kilde, men meget andet var der ikke indsamlet. Forlægger Godicke og de to fagfolk Hofman og Langebek var dog fast besluttet på at gennemføre Pontoppidans plan: værket skulle dække både Kongeriget og Slesvig under ét - Slesvigs forbindelse til Kongeriget skulle betones. Bevidstheden om Slesvig som central del af monarkiet var klar i regeringen og toneangivende kredse i København fra Christian 6.s dage og hen over århundredets midte.

Allerede i sommeren 1767 var Hofman i gang med sonderinger om den slesvigske del. Nogle år forinden havde advokat Johann Friderich Hansen i Sønderborg skrevet en kortfattet topografisk fremstillling vedr. Slesvig, som var udgivet på tryk af Anton Friedrich Büsching, og han arbejdede med en fortsættelse. Det kom på tale at benytte Hansens arbejde i det pontoppidanske værk. Men Hansen foretrak en separat udgivelse. ${ }^{37}$ Det var også på tale, at rektor Moller i Flensborg kunne påtage sig en del af arbejdet - »men hand er bedre Polyhistor end Historicus, saa at $\mathbf{i}$ fald hand skal giøre det, bliver det neppe til gauns «, skrev Hofman til Langebek den 24. juli $1767 .{ }^{38}$

Problemet var de manglende oplysninger fra Slesvig. I forordet til bind IV, som udkom i foråret 1768, opfordrede Hofman publikum til at indsende efterretninger til brug for det kommede Slesvig-bind: »Og 
som Forlæggeren er sindet at udføre Hr. Procanceller Pontoppidans fulde Plan til den Danske Atlas at faae saa vit mueligt fuldkommen, udbeder hand sig ydmygst af alle og enhver, som enten maatte besidde eller kunde vilde give nogle Efterretninger om Hertugdømmet Schleswig, at de jo før jo heller behageligst vilde til hannem indsende, da hand med største Taknemmelighed betaler paagaaende Porto, og imidlertid giør sig ald optenkelig Umage for at udfinde en lærd og velskikket Mand, der kand paatage sig at udarbeide en Beskrivning over bemeldte Hertugdom ...« 39

Den »lærde og velskikkede Mand « var Langebek. Han lovede at udarbejde værkets "sidste tome, som skal være en beskrivning over hertugdømet Slesvig «. "Således tager andres arbejde min tid bort fra mit eget og jeg har neppe såsnart et fra hånden, før jeg bliver overtalt til et andet, " sukkede han i et brev den 23. december $1767 .^{40}$

Langebek indledte arbejdet med at skaffe de nødvendige oplysninger fra Slesvig ved at udsende et tysksproget »avertissement «. Det var dateret 30. april 1768 og rettet til "amtmænd, generalsuperintendenter, amts- og andre embedsmænd, herreds- og landfogeder, stallere, magistrater i byerne, provster, præster, proprietærer, og alle curiosen Liebhabern der Geschichte des Vaterlandes«. Værket skulle tjene "fædrelandets ære og den almindelige nytte« og ville fremkomme på kongens udtrykkelige ønske, hed det. Langebek udbad sig efterretninger om Slesvigs såvel nyere som ældre tilstand hvad angår »der Antiquitæt, der Topographie, der welt-und geist. Geschichte, als auch der Merkwïrdigkeiten in der Oeconomie und Physik«. For landområderne onskede Langebek svar på spørgsmål fordelt på 12 punkter. Ligesom Thurah efterlyste han stof om »kirken, dens alder, navn, bygning, inskriptioner på epitafier og ligsten ... på marken hedenske altre, gravhøje og runesten«. Også "tegning og beskrivelse af det gamle Dannevirke, dens nuværende tilstand såvel som andre antikviteter på landet" bad han om. Men dertil spurgte han til forfatning og forvaltning, økonomi, næringsveje og dyreliv. Fra købstæder og flækker ønskedes en nærmest altomfattende beskrivelse af bysamfundets tilstand og institutioner i samtid og fortid, i alt formuleret i 26 punkter. Langebek bad også om at få et prospekt og grundrids af den enkelte by. De færdige besvarelser skulle sendes enten til Hofmans medarbejder, amtsforvalter H.A. Møller i Kolding, eller til forlæggeren, bogtrykker Godicke i København - portoen var i begge tilfælde betalt. ${ }^{41}$

Avertissementet var omstændeligt, men det er interessant, fordi det 
kombinerede interessen for de antikvariske oplysninger med en udpræget forkærlighed for samtidige oplysninger, om næringsliv, sprog, forvaltning og andre nutidsforhold. Dermed placerede Langebek fortsættelsen solidt inden for den moderne nytteprægede og økonomiske retning af topografien.

Hofman tog sig af udsendelsen af avertissementet. Inden den 10. maj 1768 var den lille tryksag sendt til alle provster, den 15 . maj gik det af sted til amterne. Fra provsterne skulle det cirkulere hos præsterne, og svarene skulle sendes samlet til Hofman på adressen amtsforvalter Møller i Kolding. Netop på denne tid var advokat Hansen $\mathbf{i}$ Sønderborg ved at færdiggøre sin store »Staatsbeschreibung» for Slesvig. Hofman fandt det derfor nødvendigt i følgebrevet at fremhæve forskellen mellem de to værker. Hofmans og Langebeks værk ville blive et leksikon med kortfattet beskrivelse af alt i Slesvig. Det ville ikke "præjudicere" - skade - Hansens arbejde, for det havde et helt andet sigte. ${ }^{42}$

Gennem provster og amtmænd nåede Langebeks »avertissement« bredt ud i Slesvig. ${ }^{43}$ Men gennemslagskraften blev mindre end for Thurah i 1754 . Dengang påberåbte Thurah sig nærmest demonstrativt, at han handlede på kongelig ordre. Hofman og Langebeks henvendelse lignede mere et privatprojekt, spørgsmålene var alt for mange, og henvendelsen var omstændelig. Embedsmændene tog derfor mindre alvorligt på den nye henvendelse. I Husum amt mente amtmanden, at alt det ønskede kunne findes i værket »Sammelung einiger Husumischen Nachrichten«, som var udgivet af Husum-borgmesteren Johannes Lass omkring 1750, og han henviste Hofman til selv at slå efter dér. Skulle der stadig være ubesvarede spørgsmål, kunne Hofman henvende sig til Lass personligt. ${ }^{44}$

Svarene indløb i de følgende måneder. ${ }^{45}$ I december 1768 videresendte Hofman eksempelvis til Langebek i København svar fra provsterne Matthias Fries i Flensborg og Balthazar Petersen i Tonder og fra andre præster. Magistraten i Slesvig lovede at ville svare, og de tre amtmænd Friderich von Klingenberg i Haderslev, G.F. von Holstein i Flensborg og U.A. von Holstein i Tønder lovede at ville hjælpe Hofman med det manglende, hvor nogle svar udeblev. Hofman var derfor fortrøstningsfuld. Han fremhævede over for Langebek, at der skulle skrives så ofte til dem, der ikke svarede, at man fik materialet komplet. Han mente også, at der var hjælp at hente i de gamle Thurah-indberetninger. „Gud give Dem Helbred og Kræfter til at fuldføre 
samme, som er en mageløs nøttig Gierning for det almindelige« sluttede han sit brev til Langebek den 4. december $1768 .{ }^{46}$

Langebek arbejdede for fuld kraft. I oktober 1769 mente han at kunne nå i mål i løbet af den kommende vinter, "dersom jeg var forsynet med alle fornødne materialier «. ${ }^{47}$ Men det trak ud. I juni 1771 spurgte Langebeks gode ven, docent Johan Henrik Lidén fra Uppsala, om Slesvig-bindet nu var færdigt. Langebek måtte benægte: "De got Folk der ude i Hertugdømmet har endnu ikke fra alle stæder og amter indsendt de fornødne efterretninger, ellers havde værket længe været færdigt «, lød det skuffede svar. ${ }^{48}$

I sommeren 1771 var man altså endnu langt fra målet. Der var huller i materialet, og udgivelsesplanen blev revideret. Hofman og Langebek valgte at fremrykke suppleringen af bind II-III, så nye oplysninger om Sjælland og Fyn-Lolland-Falster kunne fremlægges som bind VI i 1774. Det betød, at Slesvigbindet blev udskudt til bind VII.

\section{Slutspurten til Slesvig-bindet}

Først da supplementsbindet var færdigt, blev der rigtig tid til at føre Slesvig-bindet til afslutning. Men så døde Langebek i 1775. Endnu en gang blev de ufærdige forarbejder indleveret til forlæggeren Godiche, og Hofman måtte igen se at finde en vej til målet. Han foretog en sidste "spørgerunde" for at skaffe "alle de Efterretninger fra Magistrater, Proprietærer og Præster, som manglede«. I 1776 kom der beretninger fra sognene $\mathrm{i}$ Tørning len under Ribe stift. Det var bl.a. indberetninger fra Gram 1776 og Øster Lindet $1776 .{ }^{49}$ Desuden fandt Hofman nye hjælpere til det egentlige redaktions- og skrivearbejde. Han engagerede den meget duelige "evighedsstudent" Bertel Christian Sandvig (1752-86), som tjente til livets opretholdelse bl.a. som korrektør hos universitetsbogtrykker Godiche og som sekretær ved det Det genealogisk-heraldiske Selskab. ${ }^{50}$ Yderligere blev engageret »toe brave Studenter i Kiøbenhavn«. N.H. Weinwich ${ }^{51}$ fik til opgave at skrive om hertugdømmets nyere historie og Løgumkloster amt, mens H.J. Birch ${ }^{52}$, senere sognepræst i Glostrup, fik naturhistorien og Tønder amt som opgave. Enkelte afsnit havde Langebek nået at få næsten færdig, således byen Slesvig. ${ }^{53}$

I 1778 var det nye team så vidt, at trykningen kunne begynde, og i 1781 lå det færdige bind VII af Den Danske Atlas klar. Pontoppidans navn stod stadig på titelbladet, men æren tilkom de nye: Hofman 
havde med $\sin$ omfattende korrespondance skaffet de nødvendige oplysninger fra lokalsamfundene, Langebek havde været med i den første fase og sammenskrevet dele af manuskriptet. Den afsluttende bearbejdelse stod Sandvig for, hjulpet af Weinwich og Birch. I fortalen gjorde Hofman rede for tilblivelsen og forsøgte sig med en anbefaling af de trofaste hjælpere, som havde bragt det færdige værk i hus: Han håbede, at det store udførte arbejde ville blive den »uforsørgede« Sandvig til gavn. Hofman skrev: „Og da bemeldte Sandvig har vist saa megen Flid og Nøyagtighed ved dette Verkes Forfatning, saa kunde det Almindelige være tient med, om han blev allernaadigst befordret til saadan et Embede, som kunde forunde ham Tid til at arbeyde i dette Fag, hvortil han forekommer mig aldeles oplagt «. ${ }^{4}$

Måske har ordene fra den velansete Hofman haft en vis virkning. Godiches trykkeri blev nedlagt 1781, og Sandvig fik i stedet hvervet som sekretær i Det kgl. Danske Selskab for Fædrelandets Historie. Her var han frem til sin tidlige død i 1786 med til at udgive seks værdifulde hæfter i tidsskriftet Danske Magazin.

\section{Thurah som kilde til det færdige Slesvig-bind}

Det færdige Slesvig-bind fra 1781 blev som nævnt dels en generel beskrivelse af hertugdømmets "naturlige Egenskaber, Elementer, Indbyggere, Væxter, Dyr og andre Affødninger «, dels en beskrivelse sogn for sogn og by for by. Kilderne var informationer indsamlet mellem 1768 og 1780 og dertil de gamle indberetninger til Thurah fra 175455. Spørgsmålet er nu: Hvordan stykkede redaktionen det forskellige materiale sammen til det færdige værk?

Læser man sig gennem bindet bemærkes, at der er stor forskel mellem sognebeskrivelserne fra det ene amt til det andet. I Haderslev og Flensborg amter og Ejdersted ligger hovedvægten på oplysninger om kirkens bygning, inventar og historie, og der er måske oplysninger om oldtidsminder i sognet. Stof om samtidens agerbrug, kvægavl, husflid eller andre næringsveje i sognet træffer man sjældent. Det viser, at forfatterne her har taget de dengang 20 år gamle Thurahindberetninger som hovedkilde. Hvis man sammenligner Atlas-teksten med den originale Thurah-beretning, hvor den kendes, kan konstateres, at der er foretaget en kraftig redaktion af Thurah. Teksten er forkortet og strammet op omkring konkrete årstal og navne. Nogle steder har redaktørerne suppleret Thurah-teksten med korte oplys- 
ninger om den allerældste historie hentet i de notater fra diplomer og andre middelalderkilder, som lå $\mathrm{i}$ Langebeks efterladte samlinger. I Haderslev amt har de også tilføjet de aktuelle folketal fra folketællingen 1769, og de har indført oplysninger om antal gårde og skatteansættelse i sognet, formentlig hentet $\mathrm{i}$ administrationens arkiver. Undtagelser er de to sogne Gram og Øster Lindet, hvor der ikke forelå en Thurah-indberetning. Her har redaktørerne så brugt præsteindberetninger fra 1776 - næsten ordret. Det gav disse to sognebeskrivelser en helt anden og mere fyldig karakter end for de omliggende sogne. ${ }^{55}$

Redaktørernes arbejde med Thurah-kilden kan kontrolleres konkret i de tilfælde, hvor de originale indberetninger er bevaret, enten i original eller som afskrift i myndighedernes arkiver eller i den afskrift, som Flensborg-rektoren O.H. Moller foretog af indberetningerne fra Haderslev amt. I alt kendes 38 Thurah-beretninger fra 48 sogne i (datidens) Haderslev amt, fire fra Tønder og Aabenraa amter og seks fra Flensborg amt. For Sønderborg-Nordborg amt og Ærø er bevaret mindst 15 Thurah-indberetninger. ${ }^{56}$

\section{Sogneksempler}

For at vise arbejdsmåden bringes her et par eksempler, som viser, hvordan generalbygmester Laurids de Thurahs tekster blev benyttet i Danske Atlas. Fra Skodborg sogn modtog Thurah i 1754 en indberetning fra pastor Niels Ewald. Han besvarede spørgeskemaets punkt 5 om adelige gårde på følgende måde:

"5. Ingen adelige Gaarde findes her i Menigheden. Det fortælles vel af de gamle, at Sydvest herfra Byen skal i gammel Tid have staaet en Herregaard Gramgaard kaldet og findes endnu en Deel Jord, som ligger imellem Byen og Kiøbenhoved og Langetved byer i Schrau Sogn, af hvilket Jord enhver af disse trende Byer har deres Anpart, hvoraf aarlig betales en Skat for sig selv, som af Bonderne her i Byen kaldes Beistrup skat, der skal og findes en gammel Steenbro over Baistrup May, som nu med Lyng er overgroet. Men om ovenmeldte Gaard har lagt til Schrau eller Schodborg Kircke er der ingen vis Efterretning om.«

I Danske Atlas har teksten fundet følgende form, som klart røber kilden, og hvordan den er redigeret: ${ }^{57}$ 
"I Sognet har i gammel Tid staaet en Herregaard, Gramgaard kaldet, og findes endnu endeel Jord imellem Skodborg Bye og Kiøbenho, samt Langetved Byer i Schrau Sogn, af hvilken Jord enhver af disse tre Byer har deres Anpart, hvoraf aarlig betales en Skat, kaldet Beistrup Skat. Der skal og findes en gammel Steenbroe over Beistrup-May, som nu med Lyng er overgrooet; men om bemeldte Gaard har lagt til Schrau eller Skodborg vides ey. I dette Sogn er den bekiendte Erkebisp Jörgen Skodborg født.«

Samme arbejdsmåde ses for Skrave sogn. Her skrev pastor Dethlev Blangsted til Thurah om spørgsmål 1 vedr. kirken:

"1. Schrave. Kirke ligger ude fra Byerne paa Marken. Den har en spidtz Taarn og dens Bygning er i maadelig Stand. Paa den Øster Ende af Kircken ere tvende Fruentimmer udhugne i Steen. De gamles tradition er, at det skal være tvende Jomfruers Billeder, af hvilken den ene skal have bygt Kircken og den anden skal have lagt en Broe over Konge-Aaen ved Schodborg huus, hvor der endnu sees Stumper af gamle Pæle i Aaen.«

I Danske Atlas skinner præstens beretning gennem teksten på denne måde: ${ }^{58}$

»Kirken ligger for sig selv paa Marken og paa den østre Ende ere to Fruentimmer udhuggede, hvoraf den eene siges at have bygt Kirken, og den anden lagt en Broe over Konge-Aaen ved Skodborghuus, hvor der endnu sees gamle Pælestumper i Aaen. Indbyggerne ere $280 . \ll$

Tydelig er afhængigheden også i Øsby sogn, hvor pastor Christian Engel i 1754 skrev sådan til Thurah om kirken:

»1. Angaaende Kircken, da er den i Henseende til Landsbye Kircker temmelig stoer, belagt med Blye overalt og et maadeligt Taarn med en Klokke som har denne Opskrift: Hr. Aarent Fisker Præpositus. Hr. Iens Raaben Pastor. Iurati Hans Gregersen, Anders Hansen. Johan Asmussen me feet Husum Anno 1723 (det opføres, som det befindes: ellers heed den eene kircke Værger ikke Hans men Claus Gregersen og Feet skulle vel været Fucit). 

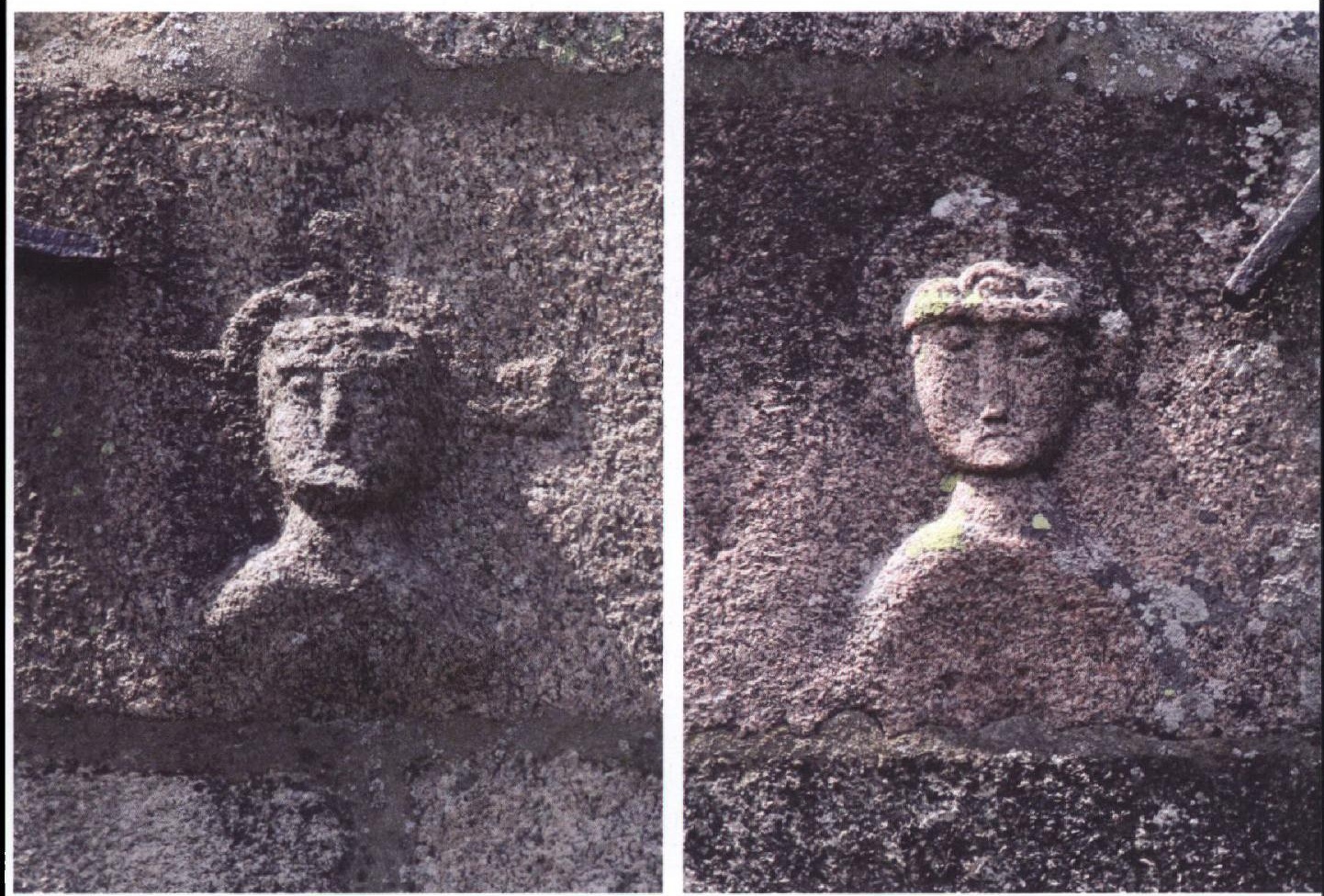

„Paa den oster Ende af Kirken ere tvende Fruentimmer udhugne $i$ Steen. De gamles Tradition er, at det skal være tvende Jomfruers Billeder, af hvilken den cene skal have bygt Kirken og den anden skal have lagt en Broe over Konge-Aaen ved Skodborg Huus, hoor der endnu sees Stumper af gamle Pale $i$ Aaen. Sädan skrev pastor Blangsted $i 1754$ til Laur. de Thurah on to hoveder på ostgavlen af Skrave kirke. Hans ord blev nxsten ordret gentaget $i$ Den Danske Atlas. I dag sidder de to hoveder stadig på deres oprindelige plads $i$ korgazlen, men der er snarere tale om dels Kristus med korsglorie, dels om en biskop med bispehue og glorie. Præsten har set meget overfladisk på de smukt udførte hoveder. Foto: Martin Bo Norregård.

Den rette Kirckedør er paa den Synder Side, med et Vaabenhuus for. Paa den Norder Side lidt meer til vesten sees og en stor Kirckedør, men ubrugelig nu og ingen kand huske at den har været i brug. Paa den øster Ende af Kirken er ved norden et Sacristie, ogsaa forsynet med en dør til Kirkegaarden. Paa den Synder Side er et Udbyk ligefor, hvor og en Dør er at gaae ind i Kircken for en deel Qvinder. Ved dette Udbyk er et Beenhuus fuld med Been. Indvendig findes nogle Bogstaver. 
Under Taarnet ved vester Siden sidder een Steen i fundamentet af en Ligsteens Størrelse der har følgende Bogstaver og Skikkelse

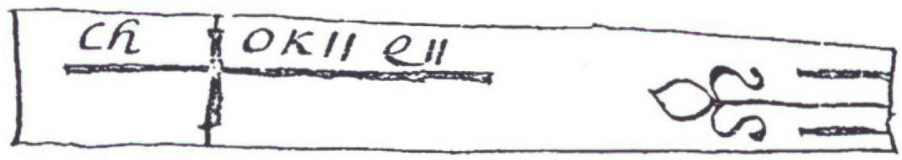

Endnu under Taarnet ved den Nordre Side findes ligesaadan een dog uden Bogstaver. Begge Stenene ligge paa Siden udi Jorden indmurede $\mathbf{i}$ den anden Grund.

Kirken indvendig bestaaer af 5 Hvelvinger, de 3 mellemste ere höyere end de andre to. Under Taarnet nederst i Kirken staar Fonten, hvorpaa intet findes at anføre.

Alter Tavlen er Træ, men Grunden er Muurverk. Paa denne findes som følger: 1614 repareret Anno 1706 I.R.P. og G.R. Navnene er Jens Ravn, Pastor og Gertrud Rauns. Hand døde 1724 og hun 1726. Deres Skilderie er med rundt Træ omgiven af Bildhugger Arbeide og opsat paa Muren ved den Nørre Side af Alteret med denne Opskrift: Gud og Kircken til Ære 1710 æt. 54-54.

Prædikestolen staar i Krogen til Norden under den anden Hvelving. Over Prædikestolen i Krogen staaer Maria med en forgyldt Krone med Barnet. Paa det øverste af Prædikestolen findes Anno 1621. C4 F4. Paa Underdelen findes to Steder det Tal 1559 og da den er repareret. Disse Bogstaver paa den nederste Kant: M.I.S. PP M.M.St. PP. I.R.P. G.R. 1706. H.A.B.

Under den tredje Hvelving paa Siden af den Norder Muur er et meget smuckt Epitaphium opsat af Italiensk Arbeid. Tvende menneskelig Gestalt og corps staaer midt paa, af hvilcke den ene forestiller Døden, den anden Evigheden. Imellem dem er en Quadrat Tavle med den Opskrift: Kircken til Prydelse og den sal. Mand Simon Bertelsen pp

Under Tavlen begge forældrenes Skilderie. Italiæneren som var her og forfærdigede Verket heed Brenno. ...«

Den fyldige Øsby-tekst blev forkortet i Danske Atlas: ${ }^{59}$

"Indbygerne ere 1240 Mennesker. Kirken, hvis Alder og gamle Navn er ubekiendt, er temmelig stor, takt med Blye og har et 


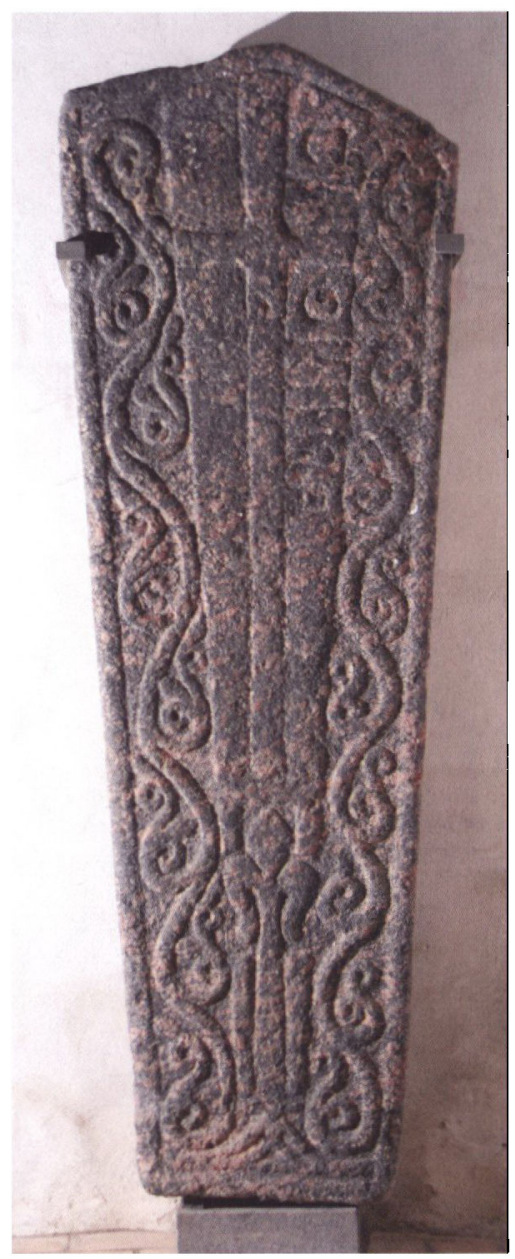

Den romanske grausten, som pastor Engel $i$ Øsby tegnede $i$ sin indberetning til Thurah, er $i$ dag indmuret $i$ tårnrummet. Den gengiver et latinsk kors, hoorunder ses en liljeagtig plante. Langs stenens lodrette sider lober en bølgeranke. Ved korset står en indskrift, som antagelig skal læses »Thora". Foto: Martin Bo Norregård.

maadeligt Taarn med en Klokke, som er støbt 1723. Paa den søndre Side er den rette Kirkedør med et Vaabenhuus, men paa den nordre Side er ligeledes en Kirkedør, dog nu af $Æ$ Elde ubrugelig. Paa den østre Ende er et Sacristie og deraf en Dør til Kirkegaarden. Paa søndre Side er et Udbyg lige for, med en Dor at gaae ind i Kirken for endeel Qvinder, hvorved er et Beenhuus, 
hvor uden paa sees nogle enkelte Bogstaver. Under Taarnets vestre Side sidder i Fundamentet en Ligsteen, hvorpaa et Kors, en Lillie og disse Bogstaver ChOKIIQII. Under den nordre Side findes og saadan en Steen med Kors og andre Figurer, dog uden Bogstaver. Indvendig bestaaer Kirken af fem Hvelvinger, hvoraf de tre mellemste ere høyest. Altertavlen er fra 1614 og er repareret 1706. Ved den nørre Side af Alteret er et Epitaphium over Hr. Jens Raun, døde 1724, og hans Hustrue Gertrud, døde 1726. Paa Prædikestolen staaer Aarstallene 1559, 1621, 1706.

Under den tredje Hvelving er ved nørre Side et Gips Epitaphium af italiensk Arbeide over Simon Bertelsen, frie Besidder paa Sparrelund, døde 1727 og hans Hustrue, som døde samme Aar. ..."

Også i Flensborg amt ses Thurah som hovedkilde. Fra Sterup sogn afgav pastor H.S. Pauli en tysksproget beretning på 9 sider i $18 \S \S$. Først var der seks punkter om sognets byer, godser, retsopdeling og skoler, derefter en fyldig beskrivelse af kirken. ${ }^{60} \S 12,14$ og 18 lød i dansk oversættelse.

$» \S 12$.

På den adelige mands- og ligeså på kvindestolen er indsnittet Claus v. Tinen og Agnes Maria v. Tinen 1627. Og på begge stole er over dette navn på den ene side udskåret i billedhugerarbejde det kendte $v$. Tinen våben og på den anden side dette våben med en hjelm foroven.«

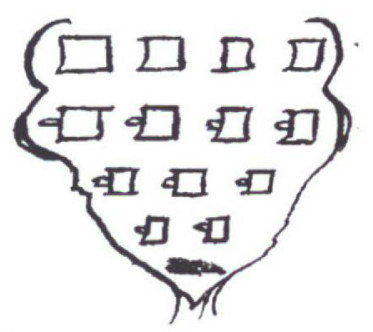

»§14.

Der står 5 messingstager på alteret til vokslys. Man benytter i 


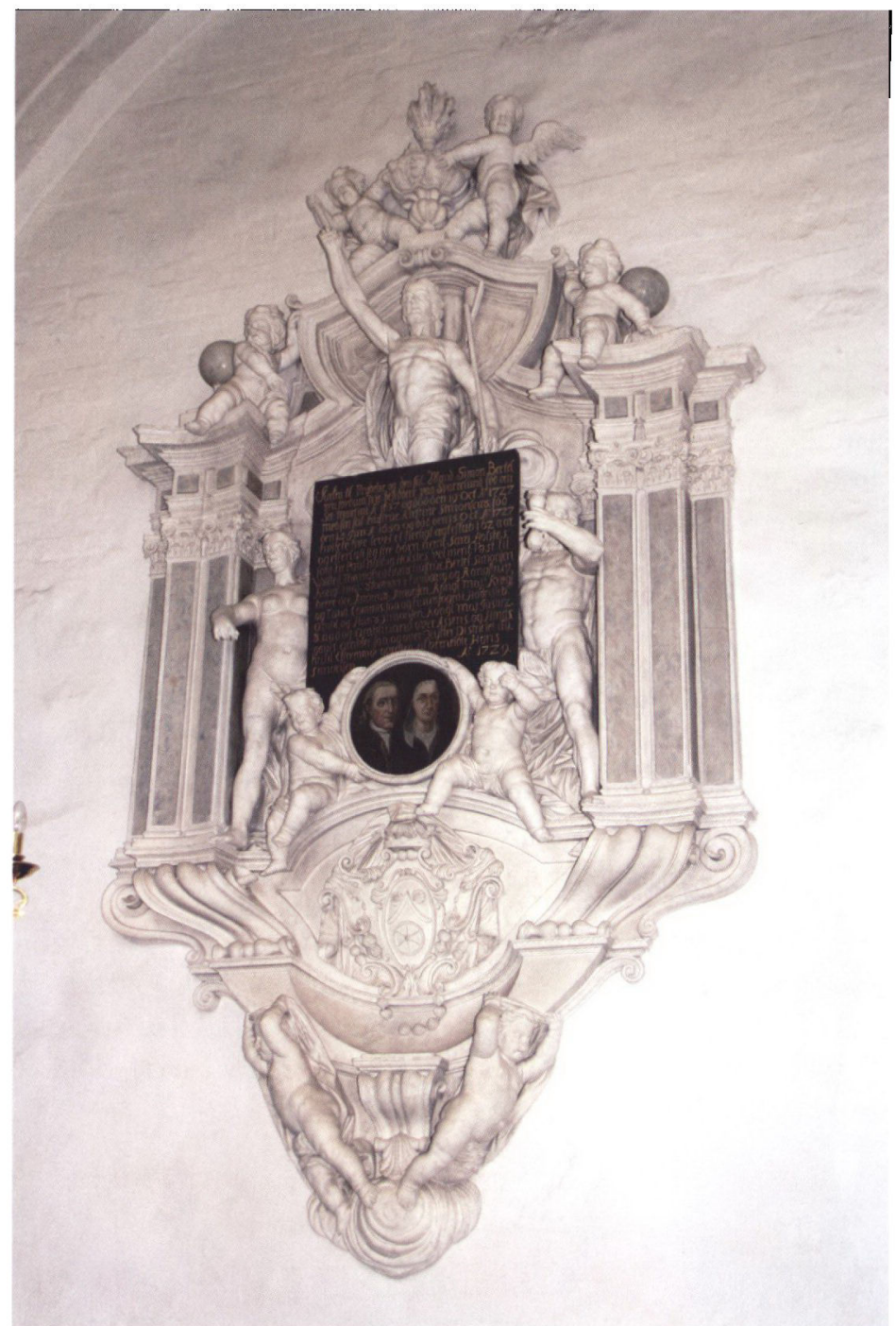

Pastor Christian Engel $i$ Øsby beskrev $i$ sin indberetning til Thurah $i 1754$ bl.a. »et meget smukt Epitaphium af Italiensk Arbeid. Tvende menniskelig Gestalt og corps staar midt paa, af hoilke den ene forestiller Doden, den anden Evigheden. Imellem dem er en quadrat Tavle med den Opskrift: Kirken til Prydelse og den sal Mand Simon Bertelsen p.p. Under Tavlen begge Forældrenes Skilderie. Italiæneren, som var her og forfardigede Verket hed Brenno." I Atlas blev det forkortet til »Under den tredie Hvelving er ved norre Side et Gips Epitaphium af italiensk Arbeide over Simon Bertelsen, frie Besidder paa Sparrelund, dode 1727 og hans Hustrue, som dade samme Aar." Epitafiet hænger uændret $i$ kirken den dag i dag. Foto Martin Bo Nørregård. 
kirken 2 sølvkalke tilligemed oblattallerkener, som er forgyldte og ikke ret store. Der er ingen tegninger og andre indskrifter derpå. Dog må ikke forbigås, at der på alteret også står et lille glas i prydelig messingindfatning, hvor man uden tvivl i pavedømmets tid har opbevaret relikvier. Der ligger endnu nogle små tøjlapper deri, som angives at være stykker af Maria og Josephs klædninger. Der skal også have været en fjer/tråd af Peters fane.«

$\gg \S 18$.

Det er i dag ikke kendt, at der har eksisteret hedenske begravelser her. Dog fandt man i 1744 tæt på landsbyen Sterup i en nyanlagt have, som tidligere lå under den fælles mark, og som efter gamle folks udsagn tidligere var dækket af store sten, da man ville så spergelplanter, nogle fod nede i jorden et gammelt instrument, som var mindst $1 \frac{1}{2}$ fod langt. Da man forst kun lagde mærke til et stykke deraf, og de der gravede af nysgerrighed først ikke ville give tid til at hele instrumentet kunne tages op på én gang, gik det i stykker; det var næsten også uundgåeligt, fordi det var ualmindelig mørt og næppe kunne berøres, uden at det gik i stykker i hænderne. Ved den øverste ende var det som en kile og derefter et rundt greb og derefter indtil den anden ende som et tveegget sværd, omkring $1 \frac{1}{2}$ tomme bredt. Skørheden fortog sig, og materialet blev meget hårdt, da det havde været ude af jorden en tid. Guldsmedene har ikke kunnet bestemme materialet men dog ment, at det kunne smeltes ligesom guld. Farven er som kronguld, og det synes at være samme materiale, som er nævnt i Dänisch Bibl. 4te B. p. 419 i den dér trykte Diss. Th. Prod. Bircherod de causis deperditarum apud septentrionales et præsertim apud Danos antiquitatum.«

Atlas-redaktionen forkortede Sterup-teksten voldsomt, men det er tydeligt, at den har ligget på deres bord: ${ }^{61}$

"Kirken er indviet til St. Laurentius, som sees af dens Segl. Her findes og hans Billedstøtte, samt et Mariebillede af Træe. Paa Altertavlen sees Christi Lidelse og de tolv Apostler i temmelig got Billedhugger-Arbeide. Fonten er af en stor Steen med et Deckel, hvorpaa staaer: Michel Lund, Cirstin Michels, Peter 
Lousen, Jörgen Lousen hebben disse Dop Deck vorehret anno 1648. Prædikestolen er af got Billedhugger-Arbeide og prydet med Christi, St. Peders, St. Andreæ, St. Jacobs og St. Johannis Billeder. Over den staaer: Jörgen Neilsen tho Sterup Michel Tilsen tho Snaab Asmes Simonsen tho Anebii 1626. Paa Grønholtgaards Stole sees to adelige Vaabener med de Navne: Claus v. Tinen og Agnes Maria v. Tinen 1627. Her findes endnu nogle Reliqviarier, med Klude i, som siges at have tilhørt Joseph og Marie. Johan Petersen til Duisberg har paa sin Bekostning ladet male og ophænge et Malerie, forestillende den yderste dag. Et andet Stykke, som her ogsaa findes, forestiller Korsfæstelsen, Himmelfarten og Dommen. Kirken har intet Taarn, men paa den vestre Side et Klokkehuus med to Klokker, den eene af 1673 og den anden af 1748. I Aaret 1744 fandtes her ved Sterup Bye i en nye anlagt Have, som for havde været Mark, et tvegget Sverd af een og en halv Fods Længde med et rundt Greb, af det beste Kobber, som i Farven ligner Krongold, og derfor i Almindelighed menes at være blandet med dette Metal. See Birc. de causis deperd. apud sept. antiqv. p. 419.

Eksemplerne viser, at hvor Thurah-kilden blev lagt til grund for Atlas-teksten, blev den forpligtet på den gammeldags antikvarisk-topografiske tradition. På disse afsnit gjaldt Pontoppidans ord, at de var »antiqvariske eller andre, alleene til curiositætens Fornøyelse hensigtende Efterretninger «, som måske mest tjente »til Sinds Forlystelse. « ${ }^{62}$

\section{»Moderne « 1768/1776-kilder i Slesvig-bindet}

Redaktorerne lod sig ikke nøje med det antikvariske Thurah-stof. Værkets mål var lige så meget at give en fremstilling af nutidens økonomisk-sociale og forvaltningsmæssige forhold. Denne nutidsorienterede dimension blev tilgodeset, hvor der enten ikke forelå en Thurah-indberetning, eller hvor der var indkommet svar på Langebeks avertissement 1768 eller på senere spørgsmål fra atlasredaktionen udsendt frem til 1780 . Sådanne nyere kilder skinner igennem mange steder. F. eks. forelå for Uge og Ensted sogne Thurah-beretninger, og de blev lagt til grund for kirkebeskrivelserne. Men atlas-beskrivelsen af næringsveje og økonomi blev hentet fra en nyere kilde. ${ }^{63}$

De nutidsorienterede indberetninger forelå formentlig især for Tøn- 
Øster Lindet - en »moderne« sognebeskrivelse 1776

Ved Langebeks »avertissement « 1768 blev der indkaldt "moderne « statisk-topografiske oplysninger til Atlas til supplement af Thurah-indberetningerne. Afsnittet om sognet Enge i Tønder Amt er nedenfor side 172 næunt som eksempel på, hvordan en præst fulgte opfordringen, og hvordan hans tekst næsten direkte blev brugt i Atlas. $\emptyset$ ster Lindet sogn er et andet eksempel. Her indsendte pastor Chr. Foersum i 1776 oplysninger til Langebeks redaktør-efterfølger Sandvig. Et uddrag kan vise, at denne indberetning fulgte de moderne retningslinjer, og at beretningen straks blev benyttet i slutredaktionen af Atlas.

Pastor Foersum skrev bl.a.

"Naring er fornemlig kornsal, iscer rug og boghvede; thi opdrat af creaturer er ej betydelig, da hoet er lidet og grcesningen ringe. - Bieavlen ligge de fleste sig efter, og finde fordeel.

Kniplinger giores her af mange, og giver unge piger, eller andre fruentimmer, der ere svage, god naring og deres ophold: $i$ de forrige aaringer, da kornet var dyre, og kniplingerne $i$ liden priis, begyndte disse arbeideres tal at formindskes, men $n u$ tiltager igien samme." (LAS Ribe bispearkiv nr. 52).

I Atlas blev det til følgende:

"Naringen er fornemmelig Korn-Salg, $i$ sar Rug og Boghvede; thi Sognet har godt Kornland. Opdrat af Creature er ey betydelig, da Høet er lidet og Groesningen ringe. Bieavl lagge de fleste sig efter, og finde fordeelagtig. Kniplinger giøres her af mange, og giver unge Piger eller andre Fruentimre god Naring og deres Ophold: $i$ de forrige Aaringer, da Kornet var dyrt, og Kniplingerne i liden Priis, begyndte disse Arbeideres Tall at formindskes, men nu tiltage de igien." (DA VII, 1 s. 171f).

der, Gottorp, Hütten, Husum amter og landskabet Bredsted. I flere sogne i Gottorp og Hütten amter blev 1768-indberetninger næsten ordret lagt til grund for sognebeskrivelsen i Atlas. ${ }^{64}$ Atlasteksten blev her meget mere ordrig og alsidig og nutidigt oplysende end andetsteds i værket. I Tønder amt blev hovedreglen, at der blev berettet bredt om hvert sogn med værdifulde oplysninger om sognets vilkår i samtiden på grundlag af præsteindberetninger fra 1768. De blev ofte ordret afskrevet, ikke stramt redigeret som praksis var for bearbejdelsen af Thurah-beretningerne i Haderslev og Flensborg amter.

Tønder amts samtidsorienterede præg var den unge Birchs fortjeneste, sådan som Hofman robede det $\mathrm{i}$ forordet. Den unge medarbejder havde skrevet naturhistorien og »vel ogsaa forfattet Beskrivelsen over Tønder Amt, men efter en anden Plan, end denne Tomes 


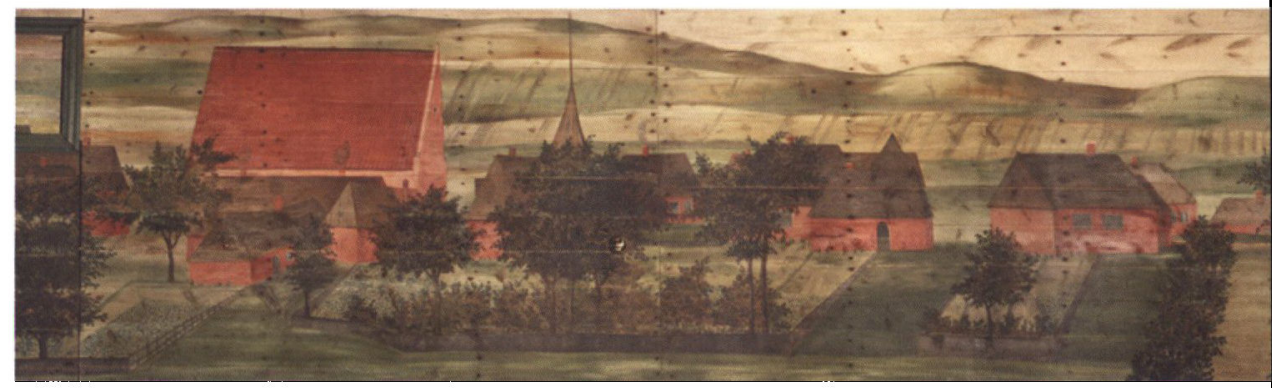

Med en rundskrivelse i 1768 indkaldte Langebek statistisk-topografiske oplysninger om sognenes nutidsforhold, erhverosliv og befolkning til Slesvig-bindet af Den Danske Atlas. I Enge sogn syd for Tonder indsendte pastor Carsten Carstensen en fyldig beretning om folk og levevilkår $i$ sognet. Den blev citeret ganske fyldigt $i$ Atlas. I 1779 fik prasten hele det store kirkeloft i sin sognekirke udsmykket med et gigantbillede af kirkebyen og dens marker. Det usædvanlige billede er en detaljeret illustration af præstens sognebeskrivelse, sådan som den fandtes $i$ hans indberetning og siden blev gengizet i Den Danske Atlas. Foto: Martin Bo Norregård.

Indretning tillod $«{ }^{65}$ Ordene virker som en kritik. Hofman taler ud fra den antikvariske tradition. I dag kan vi kun prise Birch for hans valg af en lidt anden arbejdsmåde.

Som nævnt blev der indkaldt supplerende beretninger lige frem til 1776-77, i få tilfælde til 1780. Hvor de forelå, satte de klart spor i værket. Fra godssognet Gram byggede Atlas som nævnt udelukkende på pastor Friederich Christian Claudis indberetning fra 1776. Det var en fyldig sognebeskrivelse, som ud over det antikvariske stof fortalte bredt om sognets økonomisk-sociale virkelighed. Claudis beretning fik næsten ordret plads i Danske Atlas. På samme måde gik det for nabosognet Øster Lindet og formentlig også for Okholm, Fjolde og Enge sogne og for flere sogne på $Æ$ Erø. Atlas-teksten for disse sogne tilfredsstillede derved Pontoppidans ønske om at få beskrevet »de Physiske og oeconomiske Efterretninger « ${ }^{66}$

\section{Den Danske Atlas mellem to traditioner}

Pontoppidans Den Danske Atlas blev således en kombination af 1600årenes antikvarisk-historiske tradition, som den senest var dyrket af Laurids de Thurah, med oplysningstidens interesse for en "nyttig « samfundsbeskrivelse. Folkets levevis og kultur, næringsveje og økonomiske sammenhænge og ressourcer var for oplysningstidens forfattere lige så vigtige emner som det antikvariske. De nutidsrettede emner 
blev opprioriteret, da Langebek i 1768 udsendte sit spørgeskema eller "avertissement « for at skaffe supplerende materiale til værket.

De yngre præsteindberetninger gav en bred beskrivelse af lokalsamfundene. Hvor de forelå, fandt de nærmest ufordøjet vej til Atlassiderne. Disse afsnit er særlig interessante i dag - med deres alsidige billeder af sognenes og befolkningens liv.

Spændingen mellem de to traditioner ger Slesvig-bindet af Pontoppidans Danske Atlas til et fascinerende værk.

\section{Forkortelser}

LASH: Landesarchiv Schleswig-Holstein, Slesvig

LAS: Landsarkivet for Sønderjylland, Aabenraa

LAV: Landsarkivet for Nørrejylland, Viborg

DA: Den Danske Atlas

St. A. Fl.: Stadtarchiv Flensburg

NKS: Ny kongelig Samling

\section{Noter og henvisninger}

1. Alment om Pontoppidans Atlas: Svend Cedergreen Bech: Den danske Atlas og verkets tilblivelseshistoric, 1969.

2. Chr. Bruun: Frederik Rostgaards Liv og Levnet, 1870 s. 433.

3. Om Langebek og historiebevidstheden under Christian 6, se Edvard Holm: Danmark-Norges Historie (1720-1814), bd. 2, 1894, s. 718-732. Bjørn Kornerup: Det kongelige dan- ske selskab for frdrelandets historie 1745-1945, 1945, s. 13-20.

Christian 6.5 bestræbelser for at fremme brugen af dansk i kirke og skole i Slesvig: C.F. Allen: Det danske Sprogs Historie i Hertugdommet Slesvig I, 1857, s. $157 \mathrm{ff}$.

4. Arkitekten Lauritz de Thurah 17061759. Udstilling i Kunstindustrimuseet. Selskabet for Arkitekturhistorie 1981 (katalog). 
5. Danmarks Kirker XXII Aabenraa amt, 1959, s. 1933 (Moller-Thurahsamarbejde 1749). Danmarks Kirker XX Haderslev amt, 1955, s. 499 (Øsby-indberetning til Thurah 1747). Thurah-forespørgsel til Tønder amt 11/2 1749, LASH Abt. 161 nr. 11 .

6. Arkitekten Lauritz de Thurah, Selskabet for Arkitekturhistorie 1981, s. 32.

7. "Designation « med 7 punkter, afskrift ved pastor Busch, Sdr. Kirkeby og Sdr. Alslev på Falster $7 / 7$ 1755, i Kgl. Bibl. Thott 1433, 4. Tilsvarende med 6 punkter: LAV, C 2111, Viborg bispearkiv (venligst oplyst af museumsinspektor Thomas W. Lassen).

8. Thurah til amtmændene 4. marts 1754: Haderslev: LAS Haderslev amt nr. 90, 2. Hovedregistratur s. 162, 1754, nr. 162. Aabenraa: LAS Aabenraa-Løgumkloster amter nr. 295. Tønder: LASH Abt. 161, nr. 11. Flensborg: LASH Abt. 167.1, nr. 1.

9. Provst Wöldike, Haderslev til Åstrup 28/4 1754: LAS Åstrup præstearkiv $\mathrm{BC} 1$.

Aabenraa amt til præster 11-12/ 3 1754: LAS Aabenraa-Løgumkloster amter nr. 295.

Provst Petersen, Tønder til præster 6/4 1754: LAS Tender provstearkiv 154 . Flensborg amt til provst Lundius 9/3 1754: LASH Abt. 167.1, nr. 1. Husum amt til Ejdersted-præster 5/6 1754: LASH Abt. 163, nr. 129. Gottorp amt til Stapelholm-præster 16/3 1754: LASH Abt. 170, nr. 2.

10. Eksemplarer af designationen f.eks. LAS Tonder provstearkiv 154 og LASH Abt. 167.1, nr. 1.

11. Besvarelserne fra Esgrus, Stenbjerg, Sterup, Husby, Breklum og Bredsted findes endnu i afskrift $i$ amtets arkiv, LASH Abt. 167.1, nr. 1, og 167.2, nr. 73, 258 og 270.

12. De bevarede dele af beretningerne findes i dag spredt på flere samlinger:

Afskrifter for Fyn incl. det slesvigske Sønderborg amt: Kgl. Bibl.
Kall 377.4to II; Indberetninger og samlinger vedr. Sjælland og Fyn: Kgl. Bibl. Additamenta 153, fol. 12; Afskrifter fra Viborg stift: LAV Viborg bispearkiv (jf. Fortid og $\mathrm{Nu}$ tid bd. 5, 1924-25, s. 94, og Fr. Weilbach: Architekten Lauritz Thura, 1924, s. 180-185). Indberetningerne fra Haderslev amt er bevaret $\mathrm{i}$ afskrift ved rektor O.H. Moller, Flensborg: LASH Abt. 400 I, nr. 174-175, med kopi i Rigsarkivet, Håndskriftsamlingen XI B 27.

13. I Nationalmuseet, Antikvarisk topografisk arkiv St. Fol. 92a. findes bindet »Thurah om Sjælland og Fyn«, som er Thurahs bearbejdelse af prasteindberetningerne for Sjælland og Fyn. Se også Thomas W Lassen: "Smålandenes topografiske beskrivelse ved midten af 1700-tallet. Præsteindberetninger til Laurids de Thurah", i: Kirke Mission - Folkelighed, Festskrift til Thorkild Grasholt, 1994, s. 69-76.

14. Om Arnkiel: Schleswig-Holsteinisches Biographisches Lexikon 2, 1971, s. $42 \mathrm{f}$.

15. Michael Neiiendam: Erik Pontoppidan I, 1930, s. 177f, og II, 1933, s. 60-64.

16. Pontoppidan DA VII, s. 312 (genstande fra Holbol).

17. Præsteindberetning fra Bylderup o. 1768, LAS Aabenraa provstearkiv 171a, jf. DA VII 299.

18. Ellen Jørgensen: Historieforskning og historieskrizuing $i$ Danmark indtil Aar 1800, 1964, s. 169, og Pauli-beretning $1754 \mathrm{i}$ LASH Abt. 167.2, nr. 270.

19. Sonderjyske Arboger 1993, s. 35, DA I, 1763, s. 112, og tavle X, VII, s. 297 (Ravsted). LAS Aabenraa provstearkiv 171a præsteindberetning Bylderup o. 1768.

20. Thurah-indberetning Husby 1754 , LASH Abt. 167.1, nr. 1. Lars N. Henningsen i Sonderjyske Arboger 1993, s. 37, Achelis: Die Ärate im Herzogtum Schleswig bis zum Jahre 1804, 1966, s. 19 nr. 90.

21. Ellen Jørgensen, 1964, s. 168.

22. Sonderjyllands Historie 3, 1940-42, s. 
378. Lars N. Henningsen, 1993, s. 39.

23. Således angivet $i$ Dokumentenverzeichnis des Kirchenarchivs auf Föhr 1803 (i Kirkekredsarkivet i Læk), venligst oplyst af Albert Panten, Nibøl.

24. Brev fra pastor Johannes Krag, Norre Logum 26/3 1754 til Aabenraa amt, LAS Aabenraa-Løgumkloster amter 295.

25. Manuskriptet blev af Moller overladt til historikeren P.F. Suhm og senere trykt i Langebeks værk Scriptores Rerum Danicarum VIII, 1834 , s. 1-258. Se Mackeprang i Sonderjyske Årboger 1945, s. 21.

26. DA VII, 1781, s. 158 Sommersted.

27. St. A. Fl. XII Hs 709 Bd. 2-3 katalog over Mollers håndskrifter og bibliotek. Otto Schütt: "Olaus Henrich Moller“, i: Aus Flensburgs Geschichte, 1963, s. 41-93.

28. DA VII 190f, Skærbæk.

29. Lars N. Henningsen: "Johann Friedrich Camerer - en tysk-dansk patriot i 1700-årene «, i: Sonderjyske Arboger 1993, s. 35. Samme: "J.F. Camerer - en arkæologisk pioner $\mathrm{i}$ 1700-årene«, i: Siden Saxo 1994, 1, s. 17-20.

30. I Moller-manuskriptkataloget 1797 (St.A. Fl. XII Hs 709 Bd 2) ses under kvartformater som nr. 156, 11 "Nachrichten von den Kirchen und Predigern im Amte Hadersleben« og som nr. 161 "Nachrichten von einer jeden Kirche des Amtes Hadersleben und deren Prediger von Aastrup-Wonsild «. Disse numre kan meget vel være afskrift af Thurah-indberetningerne. I dag findes afskrifterne i LASH Abt. 400 I, nr. 174, med kopi i Rigsarkivet, Håndskriftsamlingen Hs XI B 27.

31. Edvard Holm: Danmark-Norges Historie 3,2, 1898, s. 67-69.

32. $D A \mathrm{I}, 1763$ Fortale $\mathrm{XV}$, jf. Ellen Jørgensen, 1964, s. 202.

33. De såkaldte "Jessenske Relationer", se Haindbog for danske Lokalhistorikere, 1952-56, s. 293.

34. Se om Linde: Luxdorphs dagbager II, 1925-30, s. 507 register.
35. DA I, 1763 Fortale s. XVII.

36. Hofman til Langebek 4/6 1768, Kgl. Bibl. NKS 2042, 4to. Breve til Langebek 241.

37. Det skete i 1770 med bogen Vollständigere Staatsbeschreibung des Herzogthums Schlestig, Flensburg 1770 .

38. Kgl. Bibl. NKS 2042, 4to. Breve til Langebek 233.

39. Hofmanns udkast til forord dateret 29. januar $1768, \mathrm{Kgl}$. Bibl. NKS 2042.4to Breve til Langebek 236.

40. Jacob Langebek i breve 23/12 1767 og 15/4 1769, Breve fra Jacob Langebek, 1895, s. 451 og 461.

41. Avertissement 30. april 1768. Næunt DA VII, 1781 Fortale ${ }^{* *} 1$. Afskrift i LAS Aller præstearkiv $\mathbf{H}$ 6, nr. 10. Et eksemplar af den trykte udgave er ikke fundet.

42. Hofman til Langebek 10. maj 1768 , Kgl. Bibl. NKS 2042, 4to. Breve til Langebek 240.

43. Avertissementet er sporet i flere arkiver: Haderslev amt: LAS Haderslev amtsarkiv nr. 90. 2. Hovedregistratur østeramt, s. 186 . Korr. cum ceteris et vicinis $1768, \mathrm{nr} .362$. Afskrift i Aller præstearkiv $\mathrm{H} 6$, nr. 10. Husum amt: LASH Abt. 163, nr. 139, brev til Hofman 9/7 1768.

44. Husum amt til Hofman 9/7 1768, LASH Abt. 163, nr. 139.

45. Eksempler er Bylderup: LAS Tønder provstearkiv 171a. Brodersby og Taarstedt, publiceret Jahrbuch Angeln 1963, s. 47-53. Begge er næsten ordret benyttet i $D A$, VII, 299301 og 652-654.

46. Hofman til Langebek 4/12 1768, Kgl. Bibl.. NKS 2042, 4to. Breve til Langebek 242.

47. Brev 7/10 1769, Breve fra Jacob Langebek 1895 , s. 470.

48. Brev til Lidén $28 / 6$ 1771, Breve fra Jacob Langebek, 1895, s. 496.

49. Indberetning fra Gram 7/11 1776: trykt Sonderjysk Mănedsskrift, 1963, s. 272-278, gengivet næsten ordret i DA VII, 1781, s. 174-178. Øster Lindet 4/10 1776: LAS Ribe Bispearkiv nr. 52, Kalvslund og Frøs 
hrd. Reg nr. 7 capsa 6 pk. 8 , nr. 1 , jf. $D A$ VII 1781 , s. 170-172.

50. Om Sandvig se Dansk Biografisk Leksikon 3. udg. bd. 12, 1982, s. 616.

51. Niels Henrich Weinwich, 17551829, litterat. Udgav under inspiration af Langebek 1776 Historiske Efterretninger om Stevns Herred og 1777-78 sammen med Sandvig og Birch Nye kritiske Tilskuer. Se Dansk Biografisk Leksikon.

52. Hans Jørgen Birch (1750-95), sognepræst Glostrup 1779-91, 1791-95 Middelfart, forfatter og publicist. Se Dansk Biografisk Leksikon 3. udg. bd. 2,1979 , s. 144.

53. Hofman til A.G. Moltke 14/11 1778, Danske Magazin 6. rk. 3, 1923, s. 99. DA VII, 1781 Fortale ** 2 .

54. DA VII, 1781 Fortale ** 3.

55. DA VII, $170-172$ og 174-178, tilsvarende præsteindberetninger fra Øster Lindet i LAS Ribe bispearkiv 52 og Gram, trykt Senderjysk Mìnedsskrift 1963, s. 272-278.

56. Aabenraa - Tender amter: Ensted (LAS Ensted præstearkiv Cc 1), Uge (LAS Uge præstearkiv H 3), Bedsted (LAS Bedsted præstearkiv
H 1, Bov (LAS Bov præstearkiv $\mathbf{H}$ 9). Flensborg-Bredsted amter: Husby (LASH Abt 167.1-1), Esgrus (LASH Abt. 167.2-73), Steinberg (LASH Abt. 167.2-258), Sterup (LASH Abt. 167.2-270), Bredsted (LASH Abt. 167.1-1), Breklum (LASH Abt. 167.1-1). SønderborgNordborg-Ærø indberetninger: Kgl. Bibl. Kall 377,4, I-II.

57. LASSH Abt. 400 I, nr. 174-175. DA VII, 1781, s. 159 f.

58. LASH Abt. 400 I, nr. 174-175. DA VII, 1781, s. 170 .

59. LASH Abt. 400 I, nr. 174-175, DA VII, 1781, s. 140.

60. LASH Abt. 167.2, nr. 270.

61. $D A$ VII, 1781 , s. 386.

62. $D A \mathrm{I}, 1763$ Fortale XV.

63. Sammenlign Ensted-Uge-indberetningerne, jf. note 57 , med $D A$ VII, 1781 , s. $304-305$ og 307-308.

64. Sammenlign $D A$ VII, 1781 , s. 654 Brodersby-Tårsted med kilden publiceret Jahrbuch Angeln, 1963, s. 47-53.

65. DA VII, 1781 Fortale **2.

66. DA I, 1763 Fortale XV. 